\title{
$\beta$-Arrestin2 and c-Src Regulate the Constitutive Activity and Recycling of $\mu$ Opioid Receptors in Dorsal Root Ganglion Neurons
}

\author{
Wendy Walwyn, ${ }^{1}$ Christopher J. Evans, ${ }^{1}$ and Tim G. Hales ${ }^{2}$ \\ ${ }^{1}$ Department of Psychiatry and Biobehavioral Sciences, Hatos Center, University of California, Los Angeles, Los Angeles, California 90095, and \\ 2Departments of Pharmacology and Physiology, and Anesthesiology and Critical Care Medicine, The George Washington University, Washington, DC 20037
}

$\beta$-Arrestins bind to agonist-activated G-protein-coupled receptors regulating signaling events and initiating endocytosis. In $\boldsymbol{\beta}$-arrestin2 $2^{-/-}\left(\boldsymbol{\beta a r r} 2^{-/-}\right)$mice, a complex phenotype is observed that includes altered sensitivity to morphine. However, little is known of how $\beta$-arrestin 2 affects $\mu$ receptor signaling. We investigated the coupling of $\mu$ receptors to voltage-gated Ca ${ }^{2+}$ channels (VGCCs) in $\boldsymbol{\beta}$ arr $2^{+/+}$and $\boldsymbol{\beta}$ arr $2^{-/-}$dorsal root ganglion neurons. A lack of $\beta$-arrestin 2 reduced the maximum inhibition of VGCCs by morphine and DAMGO (D-Ala ${ }^{2}-\mathrm{N}$-Me-Phe ${ }^{4}$-glycol ${ }^{5}$-enkephalin) without affecting agonist potency, the onset of receptor desensitization, or the functional contribution of N-type VGCCs. The reduction in inhibition was accompanied by increased naltrexone-sensitive constitutive inhibitory coupling of $\mu$ receptors to VGCCs. Agonist-independent $\mu$ receptor inhibitory coupling was insensitive to CTAP (Cys-Tyr-D-TrpArg-Thr-Pen-Thr- $\mathrm{NH}_{2}$ ), a neutral antagonist that inhibited the inverse agonist action of naltrexone. These functional changes were accompanied by diminished constitutive recycling and increased cell-surface $\mu$ receptor expression in $\boldsymbol{\beta}$ arr $2^{-/-}$compared with $\boldsymbol{\beta}$ arr $2^{+/+}$neurons. Such changes could not be explained by the classical role of $\beta$-arrestins in agonist-induced endocytosis. The localization of the nonreceptor tyrosine kinase c-Src appeared disrupted in $\boldsymbol{\beta}$ arr $2^{-/-}$neurons, and there was reduced activation of c-Src by DAMGO. Using the Src inhibitor PP2 [4-amino-5-(4-chlorophenyl)-( $t$-butyl)pyrazolo[3,4-D]pyrimidine], we demonstrated that defective Src signaling mimics the $\boldsymbol{\beta}$ arr $2^{-/-}$cellular phenotype of reduced $\mu$ agonist efficacy, increased constitutive $\mu$ receptor activity, and reduced constitutive recycling. We propose that $\beta$-arrestin 2 is required to target $c$-Src to constitutively active $\mu$ receptors, resulting in their internalization, providing another dimension to the complex role of $\beta$-arrestin 2 and c-Src in G-protein-coupled receptor function.

Key words: opiate; analgesia; pain; desensitization; trafficking; internalization; tolerance; MOP receptor

\section{Introduction}

Agonist-bound $\mu$ opioid receptors activate inhibitory G-proteins, reducing neuronal excitability and neurotransmitter release through the combined inhibition of adenylyl cyclase, voltage-dependent $\mathrm{Ca}^{2+}$ channels (VGCCs), and activation of inwardly rectifying $\mathrm{K}^{+}$channels (Williams et al., 2001). The acute actions of $\mu$ agonists in specific neuronal pathways underlie their rewarding and analgesic properties. Opioids also cause longer-term changes in neuronal function through more complex signal transduction cascades. These actions are of considerable interest because they may contribute to the tolerance associated with prolonged opioid use.

Studies of the prototypical G-protein-coupled receptor (GPCR), the $\beta 2$ adrenergic receptor $(\beta 2 \mathrm{AR})$, reveal that

\section{Received Jan. 24, 2007; revised March 30, 2007; accepted April 1, 2007.}

This work was supported by National Institutes of Health/National Institute on Drug Abuse Grants DA05010 and DA00484. We thank Dr. R. Lefkowitz for providing $\beta$-arrestin2 ${ }^{-1-}$ mice. Flow cytometry was performed in the Jonsson Comprehensive Cancer Center and Center for AIDS Research Flow Cytometry Core Facility, University of California, Los Angeles.

Correspondence should be addressed to Tim G. Hales, Department of Pharmacology and Physiology, The George Washington University, 2300 Eye Street NW, Washington, DC 20037. E-mail: phmtgh@gwumc.edu.

DOI:10.1523/JNEUROSCI.1157-07.2007

Copyright $\odot 2007$ Society for Neuroscience $\quad$ 0270-6474/07/275092-13\$15.00/0 $\beta$-arrestins bind after receptor phosphorylation by GPCR kinases (GRKs). $\beta$-Arrestin-bound GPCRs undergo endocytosis and can either be degraded or recycled back to the cell membrane (Oakley et al., 2000; Lefkowitz and Shenoy, 2005). Agonist-induced receptor internalization and recycling promotes recovery from desensitization (Seachrist et al., 2000). $\beta$-Arrestins also orchestrate a complex pattern of $\beta 2 \mathrm{AR}$ signal transduction through intermediates such as mitogen-activated protein kinase (MAPK), Akt, phosphatidylinositol 3-kinase, nuclear factor $\kappa \mathrm{B}$, and the nonreceptor tyrosine kinase c-Src (Lefkowitz and Shenoy, 2005).

The role of $\beta$-arrestins in receptor internalization and signal transduction are somewhat receptor specific; therefore, generalization across the GPCR superfamily should be made with caution (Paing et al., 2002; Kohout and Lefkowitz, 2003). Even the highly related $\mu, \delta$, and $\kappa$ receptors exhibit different requirements for binding to $\beta$-arrestin 1 and $\beta$-arrestin2 (Cen et al., 2001) with different signaling outcomes (Oakley et al., 2000; Tohgo et al., 2003). Agonist-activated $\mu$ receptors recruit $\beta$-arrestin 1 and $\beta$-arrestin2 (Bohn et al., 2004; Haberstock-Debic et al., 2005), although the efficacy of recruitment is agonist dependent (Groer et al., 2007). Furthermore, enhanced expression of recombinant $\beta$-arrestin2 and GRKs increases the tendency for morphine to desensitize and internalize $\mu$ receptors (Whistler and von Zas- 
trow, 1998; Mace et al., 2005). Agonist-evoked internalization participates in the resensitization of $\mu$ receptors rendered tolerant to agonist (Whistler et al., 1999; Koch et al., 2005). Thus, a lack of $\beta$-arrestin 2 would be anticipated to reduce internalization and thereby promote tolerance. In practice, however, $\beta$ arr $2^{-1-}$ mice exhibit a complex phenotype of enhanced morphine analgesia and reward coupled with reduced morphine-induced tolerance, respiratory depression, and constipation (Bohn et al., 1999, 2000, 2002, 2004; Raehal et al., 2005). These findings underscore the need for a better understanding of the role of $\beta$-arrestin 2 in $\mu$ receptor signaling.

We investigated the role of $\beta$-arrestin 2 in $\mu$ receptor coupling to VGCCs in dorsal root ganglion (DRG) neurons. $\mu$ Agonists inhibited VGCCs with a lower efficacy in $\beta a r r 2^{-/-}$compared with $\beta a r r 2^{+/+}$neurons, a phenomenon associated with increased agonist-independent $\mu$ receptor coupling to VGCCs. Increased constitutive activity was accompanied by reduced constitutive recycling and elevated surface $\mu$ receptor levels in $\beta a r r 2^{-/-}$neurons. Furthermore, c-Src inhibition in $\mathrm{Barr}^{+/+}$neurons mimicked the cellular phenotype of $\beta a r r 2^{-1-}$ neurons. Importantly, c-Src was aberrantly targeted in $\beta a r r 2^{-/-}$neurons and not activated by $\mu$ agonists. Together, our findings suggest that $\beta$-arrestin 2 targets $\mathrm{c}$-Src to constitutively active receptors, thereby initiating their deactivation and recycling.

\section{Materials and Methods}

Dorsal root ganglion neuron cultures. Dorsal root ganglia were harvested from early postnatal mice [postnatal day 0 (P0) to P2], which contained both $\left(\beta_{a r r 2}^{+/+}\right)$, one $\left(\beta a r r 2^{+/-}\right)$, or neither $\left(\beta a r r 2^{-/-}\right)$of the $\beta$-arrestin2 alleles in the C57BL/6 background (Bohn et al., 1999). This line has been fully backcrossed to the C57BL/6 background, and the pups used were littermates or within two generations of $\beta$-arr2 $2^{+/-}$mating. The DRGs were enzymatically and physically dissociated, and neurons were plated in different formats and densities for specific experiments. For electrophysiology and immunocytochemistry, $5 \times 10^{4}$ dissociated cells were plated on poly-D-lysine- (Sigma, St. Louis, MO) and laminin(BD Biosciences, San Jose, CA) coated coverslips (10 mm diameter) in the center of $35 \mathrm{~mm}$ MatTek (Ashland, MA) dishes. For flow cytometry and quantitative PCR (qPCR) experiments, $1 \times 10^{6}$ cells were plated in similarly coated MatTek dishes, but the coverslips were larger $(15 \mathrm{~mm}$ in diameter). Cells were cultured in Neurobasal A, B27 (2\%), glutamax $(0.5$ $\mathrm{mM}$ ), and antibiotic-antimycotic ( $12 \mathrm{U} / \mathrm{ml}$ penicillin, $12 \mathrm{U} / \mathrm{ml}$ streptomycin, and $30 \mathrm{ng} / \mathrm{ml}$ fungizone) media (Invitrogen, Carlsbad, CA) containing NGF (10 $\mu \mathrm{g} / \mathrm{ml}$; Roche, Indianapolis, IN) and kept for $2-3 \mathrm{~d}$ in vitro at $37^{\circ} \mathrm{C}$ and $5 \% \mathrm{CO}_{2}$.

Electrophysiology. The whole-cell patch-clamp technique was used to record VGCC activity from cultured DRG neurons (Axopatch 200A amplifier; Molecular Devices, Palo Alto, CA). Culture medium was replaced by an external solution that contained the following (in $\mathrm{mm}$ ): 130 tetraethylammonium-Cl, $10 \mathrm{CaCl}_{2}, 5$ HEPES, 25 D-glucose, and 0.25 tetrodotoxin, $\mathrm{pH}$ 7.2. Recording electrodes contained the following (in mM): $105 \mathrm{CsCl}, 40$ HEPES, 5 D-glucose, $2.5 \mathrm{MgCl}_{2}, 10$ EGTA, $2 \mathrm{Mg}^{2+}$ ATP, and $0.5 \mathrm{Na}^{+}$-GTP, pH 7.2. The potential difference between the open electrode and the bath ground was zeroed before establishing a $\geq 1$ G $\Omega$ resistance seal. No compensation was made for the cancellation of liquid junction potential. $\mathrm{Ca}^{2+}$ currents were activated by depolarizing neurons from -80 to $10 \mathrm{mV}$ for $100 \mathrm{~ms}$ at $10 \mathrm{~s}$ intervals. In experiments examining constitutive inhibitory coupling to VGCCs, a two-pulse voltage protocol was used, and $\mathrm{Ca}^{2+}$ in the external solution was replaced by $\mathrm{Ba}^{2+}$ to prevent $\mathrm{Ca}^{2+}$-dependent inactivation. A depolarizing voltage step ( $80 \mathrm{~ms}$ duration) from -80 to $80 \mathrm{mV}$ preceded (by $10 \mathrm{~ms}$ ) a voltagestep from -80 to $10 \mathrm{mV}$ ( $10 \mathrm{~ms}$ duration). The current amplitude evoked by the test pulse after an $80 \mathrm{mV}$ prepulse $\left(I_{+80}\right)$ was expressed as a percentage of the current amplitude evoked by a similar test pulse in the absence of a depolarizing prepulse $\left(I_{-80}\right)$. In some instances, GTP- $\gamma$-S $(300 \mu \mathrm{M})$ was included in the recording electrode to facilitate constitutive inhibitory coupling to VGCCs. In these experiments, recordings began
$>5$ min after achieving the whole-cell configuration to allow time for GTP- $\gamma$-S to access the cell. Currents were low-pass filtered at $2 \mathrm{kHz}$ and digitized (Digidata; Molecular Devices) at $10 \mathrm{kHz}$ for storage on the hard drive of a Pentium personal computer. Leak currents were nulled using the $\mathrm{P} / 4$ subtraction method. DRG neurons were rapidly and continuously superfused $(\sim 5 \mathrm{ml} / \mathrm{min})$ with external solution in the chamber formed by the coverslip insert at the bottom of the 35-mm-diameter culture dish. The chamber had a volume of $<500 \mu$ l, allowing rapid exchange of the bath solution. Opioid agonists, opioid antagonists, baclofen (all from Sigma), and $\omega$-conotoxin GVIA (Calbiochem, La Jolla, CA) were diluted into external solution on the day of the experiment. Opioids and baclofen were rapidly applied through the perfusion system, and $\omega$-conotoxin GVIA was applied locally by pressure ejection from a micropipette. Inhibition of $\mathrm{Ca}^{2+}$ currents by opioid agonists and $\omega$-conotoxin GVIA reached maximum within 10 s of initial application. Experiments were performed at room temperature $\left(22-24^{\circ} \mathrm{C}\right)$. Mean current amplitudes were measured (pClamp 9.0; Molecular Devices) between 5 and $10 \mathrm{~ms}$ after initiating the depolarizing step. Recordings that exhibited marked rundown were discarded. Stable recordings were fitted by a linear function to compare, by extrapolation, control current amplitude with the current amplitude recorded in the presence of opioid receptor agonists. Data are expressed as mean \pm SEM and were compared using ANOVA with the post hoc Tukey's test.

$q P C R$. Cultured DRG neurons from $\mathrm{\beta arr}^{-/-}, \mathrm{\beta arr}^{+/-}$, and Barr $2^{+/+} \mathrm{P} 0-\mathrm{P} 2$ pups were harvested in PBS/EDTA, spun $(300 \times g)$ for $5 \mathrm{~min}$ at $4^{\circ} \mathrm{C}$, and lysed. mRNA was isolated (RNAqueous; Ambion, Austin, TX) and reverse transcribed (Superscript III; Invitrogen). Sequence-specific primer/probe sets (Invitrogen) for the mouse $\mu$ receptor (GenBank accession number NM_011013) and the control gene synaptophysin (GenBank accession number NM_009305) (Chen et al., 2001) were used to determine the relative transcript level, quantified by cycle number or count threshold (CT) at which the gene-specific fluorescence reached midlinear levels, using the Taqman 7700 (Applied Biosystems, Foster City, CA). The data are presented as the mean \pm SEM of the $\Delta \mathrm{CT}$ between the target and control genes for three separate experiments (supplemental data, available at www.jneurosci.org as supplemental material).

Flow cytometry. After $3 \mathrm{~d}$ in vitro, cultured $\beta a r r 2^{+/+}$and $\beta a r r 2^{-/-}$ DRG neurons were harvested in ice-cold PBS/EDTA and spun at $300 \times g$ for $5 \mathrm{~min}$ at $4^{\circ} \mathrm{C}$. The cells were washed in ice-cold PBS containing $2 \%$ fetal bovine serum and $0.1 \%$ sodium azide $\left(\mathrm{PBS} / \mathrm{FBS} / \mathrm{NaN}_{3}\right)$ and incubated with an anti- $\mu$ receptor antibody raised against the third extracellular loop, for $60 \mathrm{~min}$ at $4^{\circ} \mathrm{C}\left(1: 100\right.$ dilution in $\mathrm{PBS} / \mathrm{FBS} / \mathrm{NaN}_{3}$; Millipore, Billerica, MA). Antibodies to this region of the $\mu$ receptor do not label neuronal tissue lacking the $\mu$ receptor (Guarna et al., 2003). Thereafter, the cells were washed and incubated in the secondary antibody [allophycocyanin (APC)-conjugated rabbit IgG; 1:100; BD Biosciences] for 60 min at room temperature. After a final wash, 5000 neurons per sample were acquired on a FACScalibur flow cytometer (BD Immunocytochemistry Systems, Mountain View, CA,) and analyzed using FCS express version 3.0 (De Novo Software, Thornhill, Ontario, Canada). Flow cytometry was also used to quantify the effect of DAMGO (D-Ala ${ }^{2}-N-M e-$ $\mathrm{Phe}^{4}$-glycol ${ }^{5}$-enkephalin) on c-Src phosphorylation in cultured DRG neurons from $\beta a r r 2^{+/+}$and $\beta a r r 2^{-/-}$mice. After $2-3 \mathrm{~d}$ in culture, control DRG neurons or neurons treated with DAMGO ( $1 \mu \mathrm{M}$ for $20 \mathrm{~min}$ ) were harvested and processed as described above but, in addition, were briefly fixed ( $5 \mathrm{~min}$ ) in $2 \%$ paraformaldehyde, $\mathrm{pH} 7.4$, rinsed, and permeabilized in $0.1 \%$ Tween 20 for 5 min before labeling with two primary antibodies: anti-c-Src (mouse monoclonal antibody raised against the C-terminal sequence; Santa Cruz Biotechnology, Santa Cruz, CA) and anti-phosphorylated Y416 c-Src (rabbit polyclonal antibody; Cell Signaling Technology, Danvers, MA). Thereafter, the samples were rinsed and labeled with the secondary antibodies: anti-mouse APC-IgG (1:100; BD Biosciences) and anti-rabbit IgG Alexa 488 (1:100; Invitrogen). Such analysis of protein levels by flow cytometry allows the neuronal population to be selected (Walwyn et al., 2004) and at least two epitopes, in this case c-Src and phospho-Y416-Src, to be monitored simultaneously.

Analysis of flow cytometry. The acquired and analyzed parameters were size, (forward scatter, FSC-H), granularity (side scatter, SSC-H), and 
Alexa488 either alone or in combination with APC fluorescence, in channels FL1-H and FL4-H, respectively. Each sample within each experiment was analyzed using the same parameters of size, granularity, and FL1-H and FL4-H fluorescence. The neuronal population was first defined as region 1 (R1) by size and granularity and the Alexa488 or APC fluorescence of this population measured in FL1-H and/or FL4-H. Nonspecific fluorescence was subtracted, and the mean fluorescence intensity (FI) was obtained for each sample. Such mean FI values were normalized to the FI of the untreated $\beta a r r 2^{+/+}$or $\beta a r r 2^{-/-}$sample for each experiment. Each experiment was repeated 6-10 times, and the data were analyzed by the unpaired or paired Student's $t$ test, significance accepted at $p<0.05$, and are presented as mean \pm SEM.

Immunocytochemistry. DRG neurons from $\beta a r r 2^{+/+}$or $\beta a r r 2^{-/-}$ were cultured in $35 \mathrm{~mm}$ MatTek dishes, fixed in $4 \%$ paraformaldehyde, pH 7.4 for $5 \mathrm{~min}$, washed, permeabilized in $0.3 \%$ Triton X-100 for 10 min, and incubated in the $\mathrm{C}$-terminal rabbit anti- $\mu$ receptor antibody (Walwyn et al., 2004) or C-terminal mouse monoclonal anti-c-Src antibody (1:200; Santa Cruz Biotechnology) overnight at $4^{\circ} \mathrm{C}$ in potassium $\mathrm{PBS} / 1 \%$ normal goat serum. After an additional rinse, the secondary antibody Alexa555-conjugated anti-rabbit or anti-mouse IgG (1:1000; Invitrogen) was applied for $90 \mathrm{~min}$ at room temperature. The cells were finally washed, mounted in Slowfade (Invitrogen), and imaged using a Zeiss (Oberkochen, Germany) LSM 310 confocal laser-scanning microscope (CLSM).

\section{Results}

\section{The absence of $\boldsymbol{\beta}$-arrestin 2 reduces the efficacy of $\boldsymbol{\mu}$ agonist} inhibition of VGCCs

The activation of opioid receptors in DRG neurons causes inhibition of VGCC activity through the mobilization of pertussis toxin-sensitive inhibitory G-proteins (Williams et al., 2001). We tested the ability of $\mu, \delta$, and $\kappa$ opioid receptor agonists to inhibit $\mathrm{Ca}^{2+}$ currents activated by depolarizing $\beta \mathrm{arr} 2^{+/+}, \mathrm{\beta arr}^{+/-}$, and $\beta_{\text {arr }}{ }^{-/-}$neurons from -80 to $10 \mathrm{mV}$ (Fig. 1). Cultured mouse DRG neurons are heterogeneous (Walwyn et al., 2005). To minimize heterogeneity and maximize the fidelity of voltage clamp, we recorded from neurons with a soma diameter of $\sim 15-30 \mu \mathrm{m}$, classified previously in culture as small- to medium-sized cells (Passmore, 2005). Agonists were rapidly applied through the perfusion system to the $<500 \mu \mathrm{l}$ recording chamber. As reported previously, all wild-type DRG neurons tested responded to DAMGO $(1 \mu \mathrm{M})$, reaching maximal $\mathrm{Ca}^{2+}$ current inhibition within 10 s of DAMGO application (Walwyn et al., 2005). The inhibition evoked by DAMGO $(1 \mu \mathrm{M})$ was significantly reduced from $33 \pm 4 \%(n=12)$ for $\beta a r r 2^{+/+}$neurons to $19 \pm 4 \%(n=$ $10)$ and $14 \pm 5 \%$ for $\beta a r r 2^{+/-}$and $\beta a r r 2^{-/-}$neurons, respectively (Fig. $1 B$ ). Morphine $(1 \mu \mathrm{M})$ also caused a smaller inhibition of $\mathrm{Ca}^{2+}$ currents recorded from $\mathrm{Barr}^{-1-}$ compared with Barr $^{+/+}$neurons (Fig. $1 \mathrm{~B}$ ). In contrast, reductions of the amplitudes of $\mathrm{Ca}^{2+}$ currents, elicited by the application of the $\kappa$ receptor agonist U-50,488H [trans-( \pm )-3,4-dichloro- $N$-methyl- $\mathrm{N}$-(2[1-pyrrolidinyl]cyclohexyl) benzene-acetamide methanesulfonate] $(1 \mu \mathrm{M})$ to $\beta a r r 2^{+/+}, \beta a r r 2^{+/-}$, and $\beta a r r 2^{-/-}$DRG neurons, were not significantly different. Consistent with our previous findings, DPDPE ([D-Pen $\left.{ }^{2}, \mathrm{D}-\mathrm{Pen}^{5}\right]$-enkephalin) $(1 \mu \mathrm{M})$ had no effect on the amplitude of $\mathrm{Ca}^{2+}$ currents recorded from wild-type DRG neurons (Walwyn et al., 2005). In contrast, a small inhibitory action of DPDPE occurred in $\beta a r r 2^{-/-}$neurons (Fig. $1 B$ ).

We also tested the inhibitory response to baclofen $(50 \mu \mathrm{M})$ of VGCC activity recorded from $\beta a r r 2^{+/+}$and $\beta a r r 2^{-/-}$neurons. The $\mathrm{GABA}_{\mathrm{B}}$ receptor agonist inhibited $\mathrm{Ca}^{2+}$ currents by $46 \pm 10$ and $47 \pm 5 \%$, respectively (Fig. $1 B$ ). These data demonstrate that the deficit in inhibitory coupling to VGCCs in DRG neurons, caused by the absence of $\beta$-arrestin2, does not apply to all GPCRs.
We examined whether reduced inhibitory coupling between $\mu$ receptors and VGCCs in $\beta$ arr $2^{-/-}$DRG neurons results from a reduction in the potency and/or efficacy of DAMGO (Fig. 1C). DAMGO $(0.01-3 \mu \mathrm{M})$ caused a concentration-dependent inhibition of $\mathrm{Ca}^{2+}$ currents in both $\beta a r r 2^{+/+}$and $\beta a r r 2^{-/-}$DRG neurons. Logistic fits to the data revealed that DAMGO inhibited $\mathrm{Ca}^{2+}$ currents with $\mathrm{IC}_{50}$ values of $0.10 \pm 0.02$ and $0.18 \pm 0.10 \mu \mathrm{M}$ for $\beta a r r 2^{+/+}$and $\beta a r r 2^{-/-}$, respectively, which were not significantly different (Fig. 1C). In contrast, there was a significant reduction in the maximum inhibition by DAMGO in $\beta a r r 2^{+/+}$ compared with $\beta a r r 2^{-/-}$neurons (Fig. 1C).

\section{$\boldsymbol{\beta a r r}^{-/-}$DRG neurons have more cell-surface $\boldsymbol{\mu}$ receptors than do $\boldsymbol{\beta a r r}^{+/+}$DRG neurons}

There are several factors that could reduce the efficacy of $\mu$ receptor coupling to VGCCs. The most obvious possibility is that there is a reduction in the number of $\mu$ receptors in the membranes of $\beta a r r 2^{-1-}$ DRG neurons. Initial analysis by CLSM showed no obvious difference in $\mu$ receptor immunolabeling (Fig. 2A). However, quantification of cell-surface $\mu$ receptor labeling of intact $\beta a r r 2^{+/+}$and $\beta a r r 2^{-/-}$DRG neurons by flow cytometry (Fig. $2 B, C$ ) revealed a small increase $(p<0.05$, Student's $t$ test) in surface expression of $\mu$ receptors in $\beta a r r 2^{-/-}$to $127 \pm 11 \%$ of that in $\beta$ arr $2^{+/+}$DRG neurons $(n=8$; data not shown).

We used qPCR to examine whether the increased receptor surface expression of $\mu$ receptors in $\beta a r r 2^{-1-}$ compared with arr $^{+/+}$neurons was caused by increased gene expression. RNA was isolated from $\beta$ arr $2^{+/+}, \beta a r r 2^{+/-}$, and $\beta a r r 2^{-/-}$DRG neurons after $2 \mathrm{~d}$ in culture, and expression of the $\mu$ receptors was determined by qPCR using a sequence-specific primer probe set. The expression of synaptophysin was determined in each reaction as a control gene (Chen et al., 2001). The CT revealed that the expression of the $\mu$ receptor relative to synaptophysin was similar in $\beta a r r 2^{+/+}, \operatorname{\beta arr}^{+/-}$, and $\beta a r r 2^{-/-}$DRG neurons (supplemental data, available at www.jneurosci.org as supplemental material). Therefore, increased $\mu$ receptor cell-surface expression in $\mathrm{Barr}^{-/-}$neurons does not reflect increased gene expression.

\section{Desensitization of $\mu$ receptor inhibitory coupling to VGCCs in $\boldsymbol{\beta a r r}^{+/+}$and $\boldsymbol{\beta a r r} 2^{-/-}$neurons}

Because there is no reduction in $\mu$ receptor number in $\beta a r r 2^{-/-}$ compared with $\beta$ arr $2^{+/+}$DRG neurons, we looked for alternative explanations for reduced VGCC coupling efficacy in the former. Enhanced agonist-induced $\mu$ receptor desensitization in Barr $^{-/-}$neurons may reduce the apparent $\mathrm{Ca}^{2+}$ current inhibition by DAMGO and morphine. We measured the peak level of $\mathrm{Ca}^{2+}$ current inhibition by DAMGO $(1 \mu \mathrm{M})$ or morphine $(1 \mu \mathrm{M})$ and compared it with the level of inhibition after $200 \mathrm{~s}$ of exposure to the agonists to quantify acute $\mu$ receptor desensitization (Fig. 3A). After $200 \mathrm{~s}$, the inhibition of $\mathrm{Ca}^{2+}$ current amplitude by DAMGO $(10 \mu \mathrm{M})$ declined to $57 \pm 12 \%(n=5)$ and $44 \pm 8 \%$ $(n=5)$ of the initial peak inhibitions in $\mathrm{Barr}^{+/+}$and $\mathrm{\beta arr}^{-/-}$ neurons, respectively (Fig. $3 B$ ). Likewise, there was no difference in the level of acute desensitization elicited by morphine $(10 \mu \mathrm{M})$, $200 \mathrm{~s}$ exposure caused a decline in the inhibition to $37 \pm 15 \%$ $(n=3)$ and $45 \pm 7 \%(n=4)$ of the initial peak inhibitions in Barr2 $^{+/+}$and Barr $^{-/-}$neurons, respectively (Fig. 3B). Therefore, the absence of $\beta$-arrestin 2 does not significantly alter the level of acute $\mu$ receptor desensitization. 
A

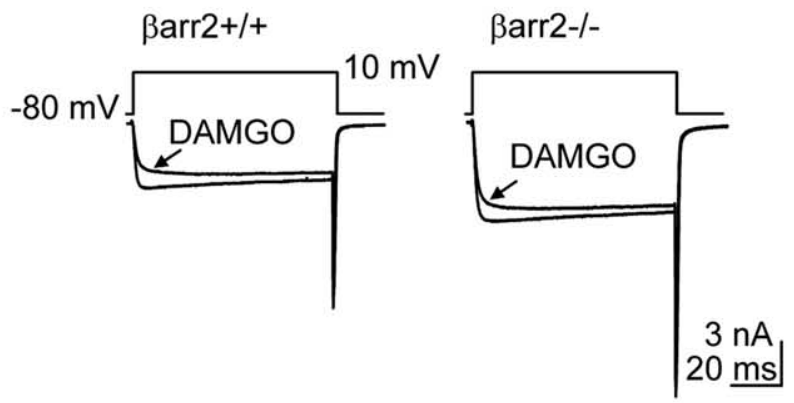

B
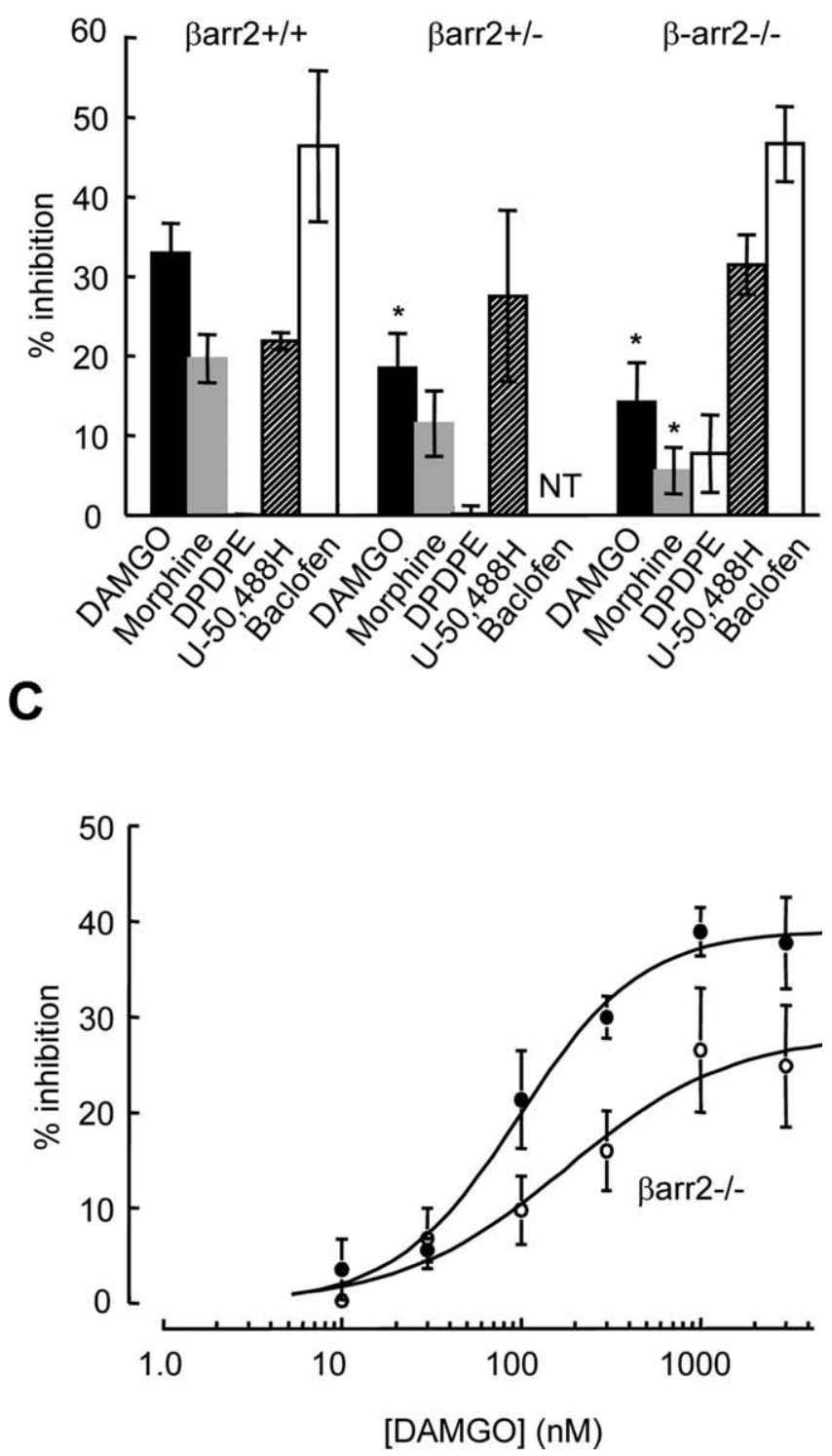

Figure 1. The absence of $\beta$-arrestin2 reduces the efficacy of $\mu$ receptor coupling to VGCCs. $A$, Whole-cell $\mathrm{Ca}^{2+}$ currents mediated by VGCC recorded from $\beta a r r 2^{+/+}$and $\beta a r r 2^{-/-}$DRG neurons in the absence and presence of DAMGO $(1 \mu \mathrm{m})$. Neurons were depolarized from -80 to $10 \mathrm{mV}$. $\boldsymbol{B}$, The bar graph illustrates the amplitudes of opioid and $\mathrm{GABA}_{B}$ receptor-mediated inhibition of $\mathrm{Ca}^{2+}$ currents recorded from DRG neurons. Opioids were tested on $\beta a r r 2^{+/+}$, $\beta a r r 2^{+/-}$, and $\beta a r r 2^{-/-}$neurons. Baclofen $(50 \mu \mathrm{m})$ was tested on $\beta a r r 2^{+/+}$and $\beta a r r 2^{-/-}$neurons but was not tested (NT) on $\beta a r r 2^{+/-}$neurons. Opioids were applied at a concentration of $1 \mu \mathrm{M}$, and $\mathrm{Ca}^{2+}$ currents were recorded as indicated in $\boldsymbol{A}$. Error bars represent \pm SEM. Statistical significance was determined by ANOVA with post hoc Tukey's test, ${ }^{*} p<0.05$ compared with inhibition of $\mathrm{Ca}^{2+}$ current amplitude by the agonist when applied to
The absence of $\boldsymbol{\beta}$-arrestin 2 does not alter the current density of VGCCs or the proportion of N-type to non-N-type VGCCs in DRG neurons

It is possible that reduced inhibition of VGCCs by $\mu$ agonists could be caused by a deficit in G-protein-sensitive $\mathrm{Ca}^{2+}$ channels in $\beta_{a r r 2^{-1}}$ DRG neurons. Opioid receptors couple to highvoltage-activated $\mathrm{Ca}^{2+}$ channels (Williams et al., 2001). We compared the densities of $\mathrm{Ca}^{2+}$ current in $\beta a r r 2^{+/+}$and $\beta a r r 2^{-/-}$ DRG neurons over a range of voltages (Fig. 4). Currents activated in $\beta a r r 2^{+/+}$and $\beta a r r 2^{-/-}$neurons, by depolarizing steps from -60 to $70 \mathrm{mV}$ in $10 \mathrm{mV}$ increments, appeared similar (Fig. 4A). Furthermore, when peak current amplitudes were normalized to the cell membrane capacitance $(\mathrm{pA} / \mathrm{pF})$, the resultant densities of current were similar at all voltages examined (Fig. $4 B$ ). These data suggest that the absence of $\beta$-arrestin2 does not cause a significant change in the expression of functional VGCCs.

In DRG neurons, opioid agonists predominantly inhibit the activity of N- and P/Q-type VGCCs (Rusin and Moises, 1995). Furthermore, $\beta$-arrestin1 has been implicated in the internalization of N-type channels (Puckerin et al., 2006). Therefore, we investigated the possibility that the absence of $\beta$-arrestin 2 could also affect the contribution of $\mathrm{N}$-type $\mathrm{Ca}^{2+}$ channels. Application of the selective N-type channel inhibitor $\omega$-conotoxin GVIA (10 $\mu \mathrm{M})$ from a local pressure pipette inhibited the amplitude of $\mathrm{Ca}^{2+}$ currents recorded from $\beta$ arr2 ${ }^{+/+}$neurons by $55 \pm 5 \%(n=$ 7) (Fig. 5A). The inhibition peaked within $10 \mathrm{~s}$, was irreversible during a prolonged wash, and ranged from 43 to $73 \%$. Application of $\omega$-conotoxin GVIA caused a similar inhibition $(51 \pm 2 \%$; $n=5$ ) of $\mathrm{Ca}^{2+}$ currents recorded from $\beta a r r 2^{-/-}$neurons (Fig. $5 B)$. The inhibition by DAMGO $(1 \mu \mathrm{M})$, after application of $\omega$-conotoxin GVIA, was reduced to $21 \pm 4 \%(n=7)$ and $10 \pm$ $4 \%(n=4)$ in $\beta a r r 2^{+/+}$and $\beta a r r 2^{-/-}$neurons, respectively (Fig. $5 A, B)$. The reduction in the efficacy of DAMGO as an inhibitor of $\omega$-conotoxin GVIA-insensitive current caused by a lack of $\beta$-arrestin 2 was similar to the reduction seen in the absence of $\mathrm{N}$-type channel inhibition. In the presence of $\omega$-conotoxin GVIA, DAMGO inhibition of $\mathrm{Ca}^{2+}$ current in $\beta a r r 2^{-/-}$neurons was $\sim 48 \%$ of that in $\beta a r r 2^{+/+}$neurons compared with $\sim 42 \%$ in the absence of $\omega$-conotoxin GVIA. Furthermore, as mentioned above, baclofen, which also inhibits N- and P/Q-type channels, caused a similar level of inhibition in $\beta a r r 2^{+/+}$and $\beta a r r 2^{-/-}$ neurons (Fig. $1 B$ ), suggesting that there is no change in the contribution of these channels in the absence of $\beta$-arrestin2.

Together, these data suggest that the reduction in the inhibition by DAMGO caused by the absence of $\beta$-arrestin 2 was attributable to neither a change in the level of N-type VGCCs nor a shift in the proportion of the $\mu$ receptor inhibitory coupling from $\mathrm{N}$-type to non-N-type VGCCs.

\section{The absence of $\boldsymbol{\beta}$-arrestin 2 does not reduce G-protein} coupling to VGCCs

Because in $\beta a r r 2^{-/-}$DRG neurons there is (1) no reduction in the number of $\mu$ receptors, (2) unaltered desensitization after

Barr $^{+/+}$neurons. C, DAMGO caused a concentration-dependent inhibition of $\mathrm{Ca}^{2+}$ currents recorded from $\beta a r r 2^{+/+}$and $\beta a r r 2^{-/-}$neurons. Data points are mean percentage inhibitions recorded from at least five cells. The logistic fits to the data were used to determine the $\mathrm{IC}_{50}$ value $\left(\beta a r r 2^{+/+}, 97 \pm 17 \mathrm{~nm}\right)$, which was not significantly affected by the absence of $\beta$-arrestin2 ( $\beta$ arr2 ${ }^{-/-}, 177 \pm 95 \mathrm{~nm}$ ). In contrast, the maximum DAMG0-evoked inhibition of $\mathrm{Ca}^{2+}$ currents determined by the logistic fit to $\beta a r r 2^{-\prime-}$ data were significantly reduced ( $28 \pm 5 \%)$ compared with the fit to $\beta a r r 2^{+/+}$data $(39 \pm 2 \% ; p<0.05$, Student's $t$ test). Error bars represent \pm SEM. 

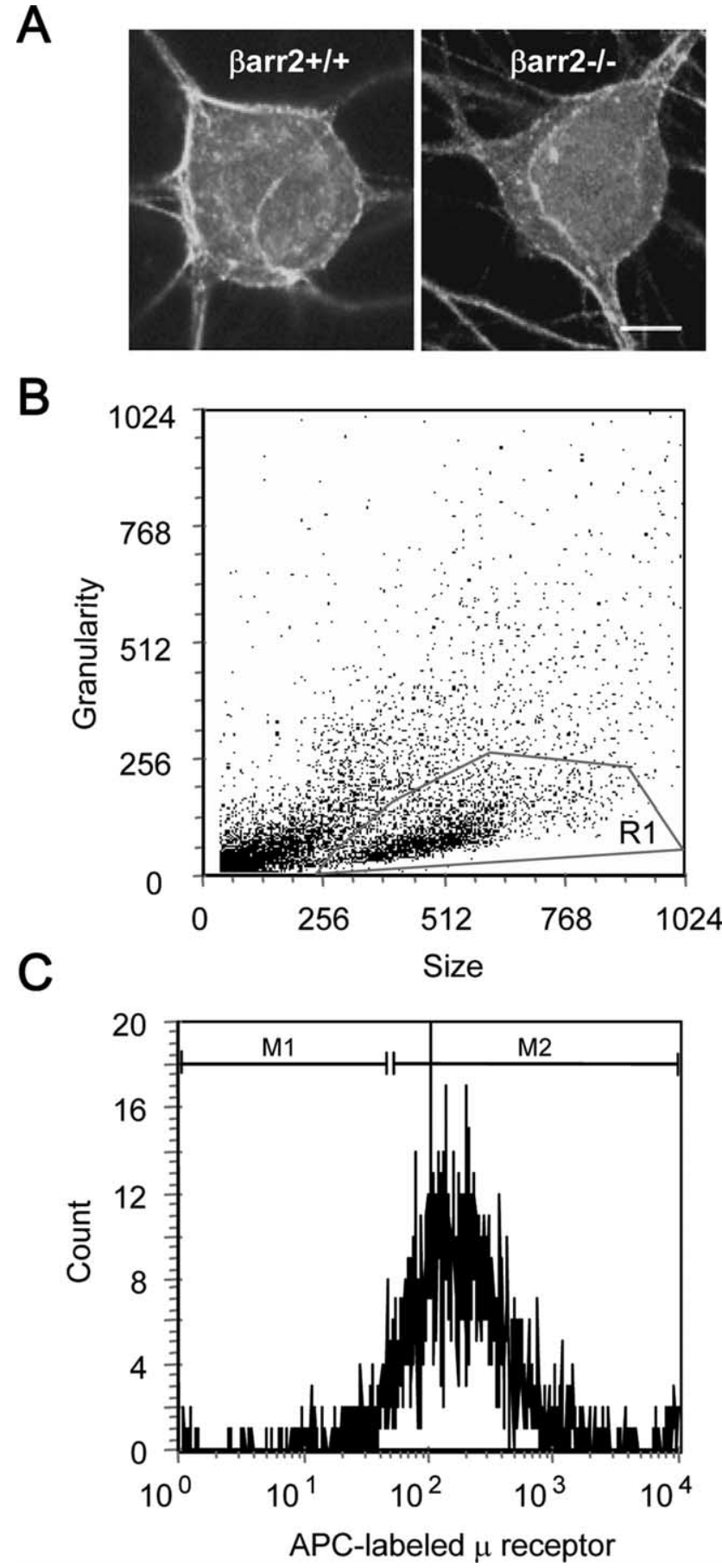

Figure 2. Confocal laser-scanning microscopy and flow cytometry to detect cell-surface $\mu$ receptors in DRG neurons. $A$, Confocal laser-scanning microscopy reveals no obvious difference in the cellular localization of the $\mu$ receptor in $\beta a r r 2^{-/-}$and $\beta a r r 2^{+/+}$neurons. Scale bar, $10 \mu \mathrm{m}$. $\boldsymbol{B}$, Flow cytometry was used to quantify cell-surface $\mu$ receptor levels in $\beta$ arr2 ${ }^{-/-}$and $\beta$ arr $2^{+/+}$neurons. In all experiments, the neuronal population was first defined by the nonfluorescent parameters of size (FSC-H) and granularity (SSC-H) and labeled as R1. C, The mean fluorescence of the APC-labeled $\mu$ receptor of these $R 1$ cells was then obtained (M2) after removing nonspecific background fluorescence (M1). Including neurons from $\beta a r r 2^{+/+}$and $\beta a r r 2^{-/-}$neurons in the same experiment allowed a quantitative comparison of relative receptor levels across genotype revealing an increase in $\mu$ receptor levels in Barr2 $^{-1-}$ neurons (see Results).

exposure to DAMGO, and (3) an apparently normal complement of functional VGCCs, we next examined the possibility of defective transduction between the $\mu$ receptor and effector.

Inhibitory coupling of GPCRs to N-type channels in DRG
A $\beta$ arr $2+/+$

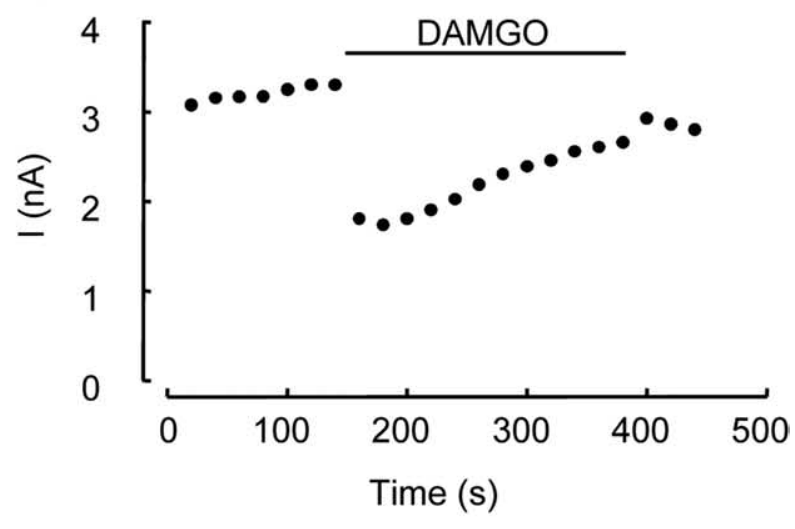

Barr2-/-
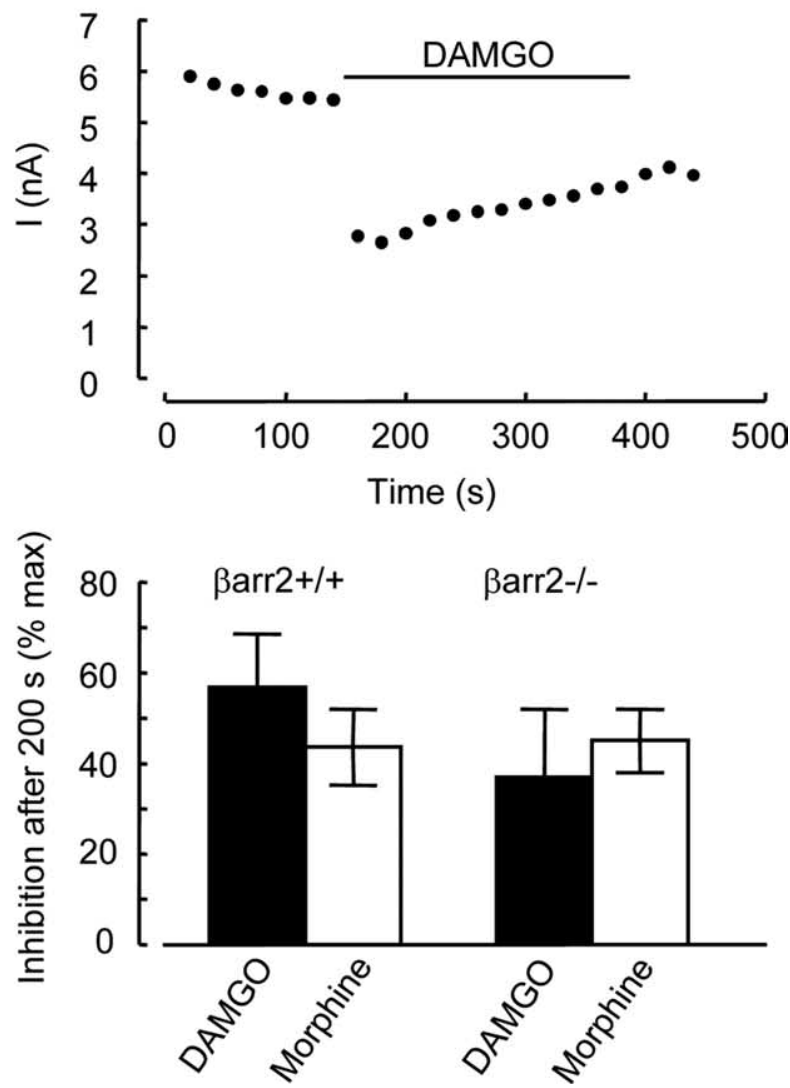

Figure 3. Desensitization of inhibitory coupling of $\mu$ receptors to VGCCs is similar in Barr2 ${ }^{+/+}$and $\beta a r r 2^{-/-}$neurons. A, Time course of inhibition by DAMGO $(10 \mu \mathrm{m})$ applied for 200 s to $\beta a r r 2^{+/+}$(top) and $\beta a r r 2^{-/-}$(bottom) neurons. $\mathrm{Ca}^{2+}$ currents were activated by depolarizing from -80 to $10 \mathrm{mV}$ using the voltage protocol illustrated in Figure $1 \mathrm{~A}$. Peak current amplitudes $(\mathrm{pA})$ were measured and plotted against time. $\boldsymbol{B}$, The inhibition of $\mathrm{Ca}^{2+}$ current amplitude measured after $200 \mathrm{~s}$ of exposure to either DAMGO $(10 \mu \mathrm{M})$ or morphine (10 $\mu \mathrm{M}$ ) was expressed as a percentage of the peak inhibition observed at the beginning of opioid application. Error bars represent \pm SEM.

neurons has both voltage-dependent and voltage-independent components (Diverse-Pierluissi et al., 1995; Raingo et al., 2007). The direct interaction of the $\beta \gamma$ subunits with the VGCCs is voltage dependent (Ikeda, 1996). Strong depolarization reverses this interaction and facilitates current in the presence of GPCR activation. In contrast, voltage-independent coupling remains in the presence of strong depolarization. Thus, a reduced efficacy of opioid receptor coupling to VGCCs in $\beta a r r 2^{-/-}$neurons could 
A

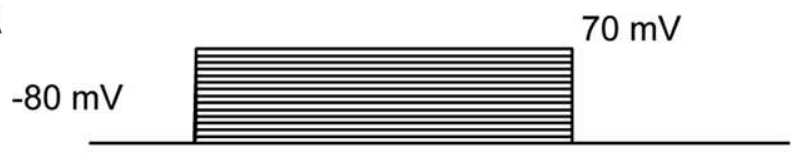

Barr2+/+

Barr2-/-
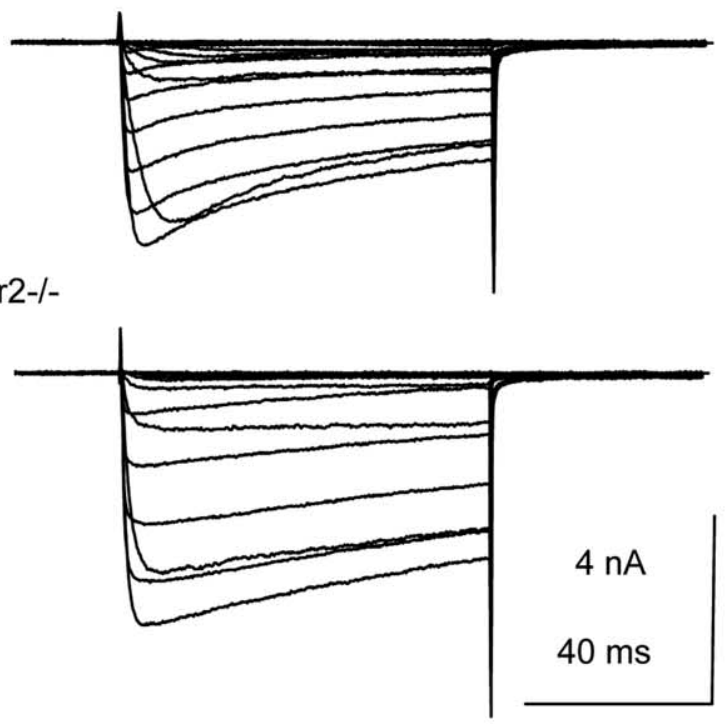

B

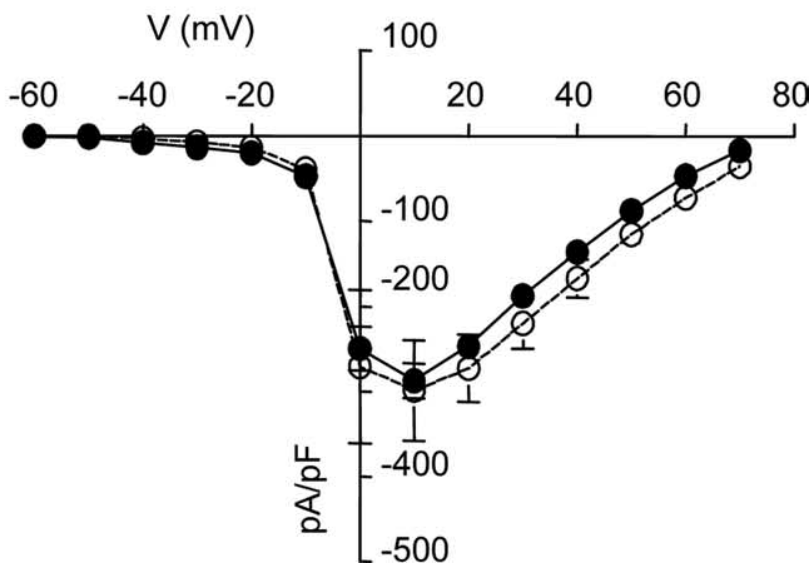

Figure 4. The densities of $\mathrm{Ca}^{2+}$ current mediated by VGCCs are similar in $\beta a r r 2^{+/+}$and $\beta a r r 2^{-/-}$neurons. A, Superimposed $\mathrm{Ca}^{2+}$ currents recorded from $\beta a r r 2^{+/+}$(top) and Barr2 $^{-/-}$(bottom) DRG neurons in response to voltage steps from $-80 \mathrm{mV}$ to between -60 and $70 \mathrm{mV}$ (10 mV increments every $15 \mathrm{~s}$ ). $\boldsymbol{B}$, The graph illustrates the densities of currents [determined by dividing peak current amplitudes $(\mathrm{pA})$ by membrane capacitance $(\mathrm{pF})$ ] at all voltages tested in $\beta a r r 2^{+/+}$(filled circles) and $\beta a r r 2^{-/-}$(open circles) neurons. Each data point represents the mean current density obtained from at least five cells.

be associated with a shift in the relative contribution of voltagedependent and voltage-independent inhibitory components. To test this hypothesis, we compared the ability of a strong depolarization to reverse the inhibition of VGCCs by DAMGO and GTP$\gamma$-S in $\beta a r r 2^{+/+}$and $\beta a r r 2^{-/-}$neurons (Fig. 6). We used a twopulse protocol to examine the effects of a prepulse $(80 \mathrm{~ms}$ duration) to $80 \mathrm{mV}$ delivered $10 \mathrm{~ms}$ before a test pulse $(10 \mathrm{~ms}$ duration) to $10 \mathrm{mV}$ (Fig. $6 \mathrm{~A}$ ). We used $\mathrm{Ba}^{2+}$ as the charge carrier in these experiments to avoid possible $\mathrm{Ca}^{2+}$-dependent inactivation of VGCCs. Control currents recorded from $\beta a r r 2^{+/+}$neurons with a preceding prepulse $(+\mathrm{PP})$ to $80 \mathrm{mV}$ were $97 \pm 2 \%$
A
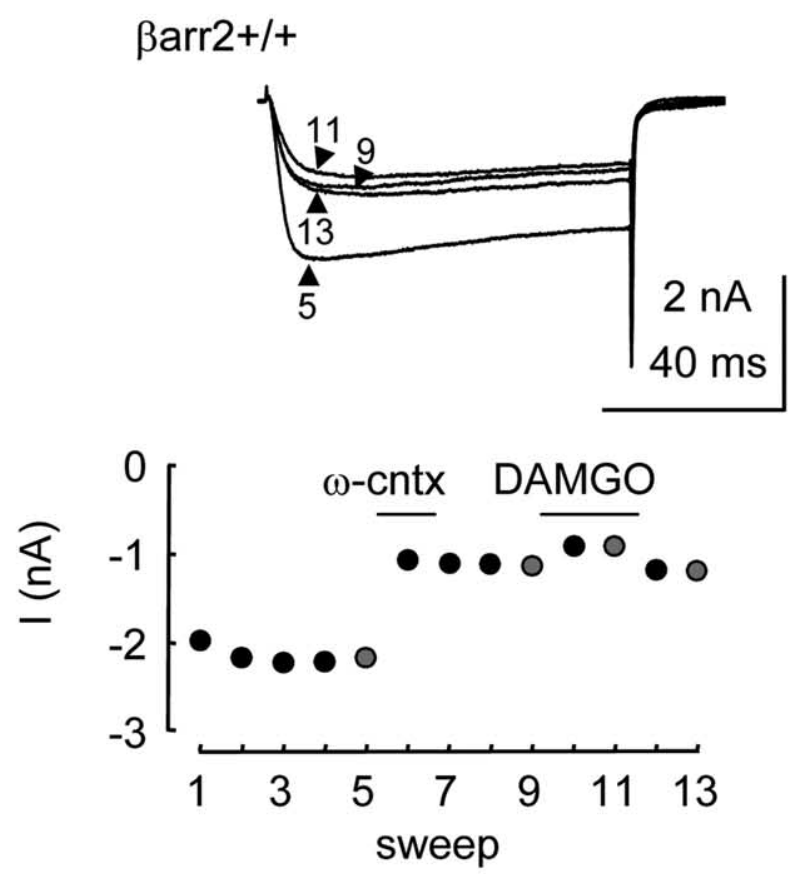

B

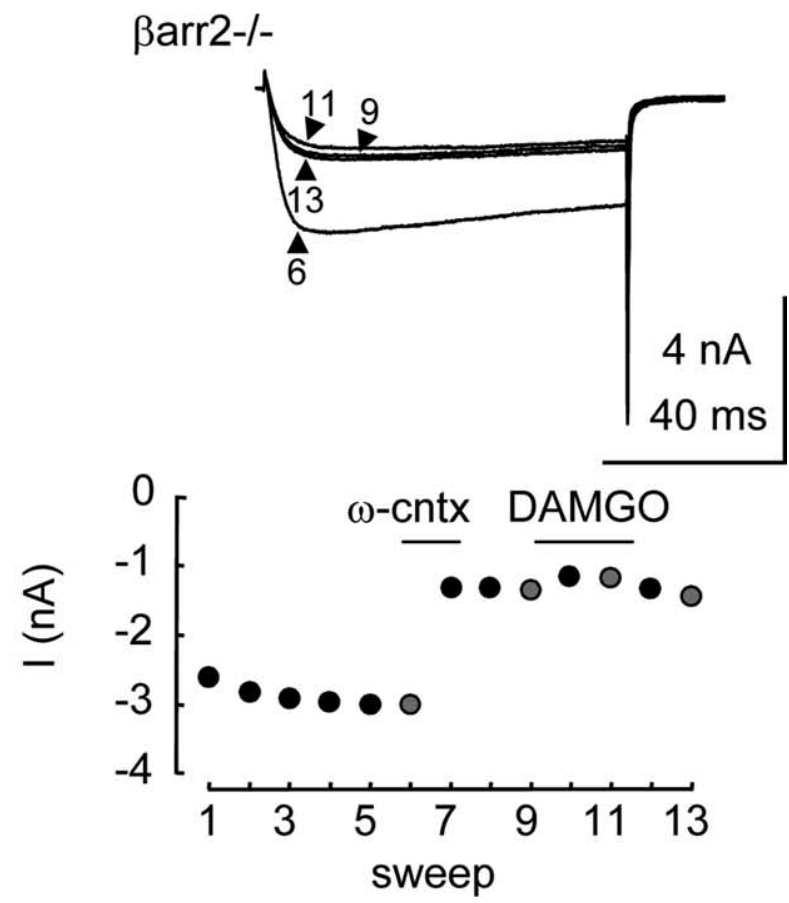

Figure 5. N-type VGCCs contribute equally to $\mathrm{Ca}^{2+}$ currents recorded from $\beta a r r 2^{+/+}$and $\beta a r r 2^{-/-}$neurons. The application of $\omega$-conotoxin GVIA ( $\omega$-cntx) inhibited currents recorded from $\beta a r r 2^{+/+}$and $\beta a r r 2^{-1-}$ neurons. $A$, Traces are $\mathrm{Ca}^{2+}$ currents recorded (using the protocol in Fig. $1 \mathrm{~A}$ ) in the absence and presence of $\omega$-conotoxin GVIA (10 $\mu \mathrm{M})$ and DAMGO (1 $\mu M$ ) at sweeps $5,9,11$, and 13 in the plot of current amplitude versus time in the graph below. $B$, Traces are $\mathrm{Ca}^{2+}$ currents recorded at sweeps 6,9,11, and 13 in the plot of current amplitude versus time in the graph below.

( $n=14)$ of the amplitude of currents recorded in the absence of a prepulse $(-\mathrm{PP})$ (Fig. $6 A)$. Interestingly, the prepulse caused a significantly $(p<0.05)$ larger increase $(106 \pm 3 \% ; n=9)$ in current amplitude in experiments performed on $\beta a r r 2^{-/-}$neurons (Fig. $6 D)$. After the application of DAMGO $(1 \mu \mathrm{M})$, the depolarizing prepulse caused a marked facilitation of $\mathrm{Ba}^{2+}$ currents evoked by the test pulse compared with those recorded in 
A

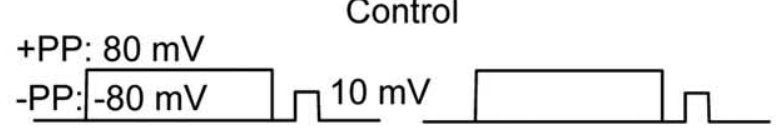

Barr2+/+ Barr2-/-

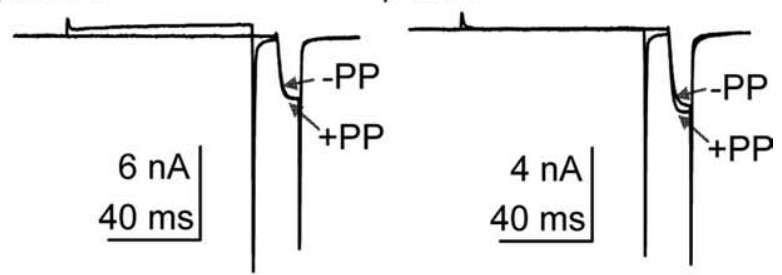

B

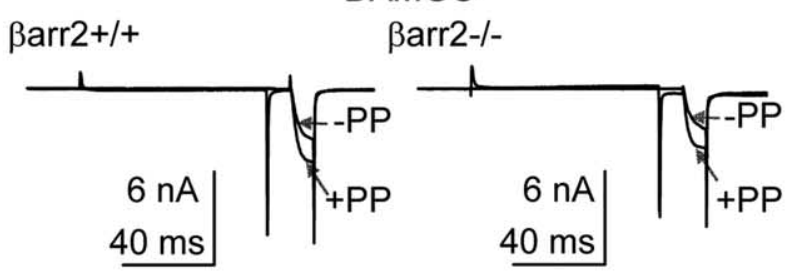

C

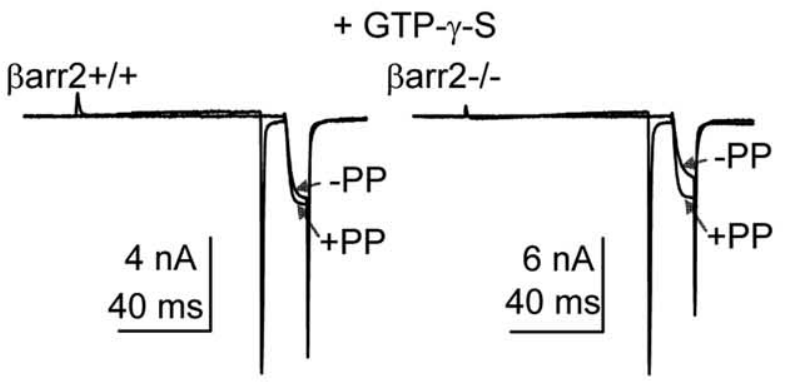

D

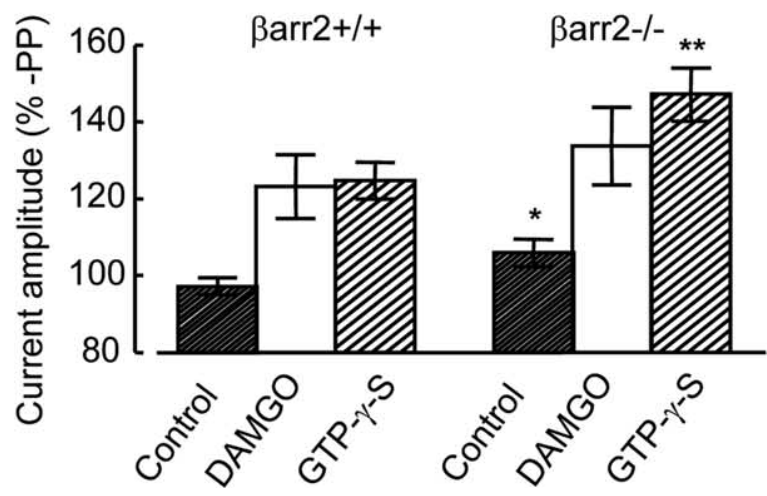

Figure 6. The absence of $\beta$-arrestin2 increases voltage-dependent facilitation of VGCCS recorded from DRG neurons. $A$, Typical control whole-cell $\mathrm{Ba}^{2+}$ currents recorded from Barr2 $^{+/+}$(left) and arr2 $^{-/-}$(right) neurons. Currents were evoked using the two-step voltage protocol illustrated above. The first sweep contains a single $10 \mathrm{~ms}$ test pulse to $10 \mathrm{mV}$ from $-80 \mathrm{mV}$. In the second sweep, the test pulse is preceded by a prepulse from -80 to 80 $\mathrm{mV}$. Each trace depicts two current sweeps recorded from the same cell in the presence (+PP) and absence ( $-P P)$ of a depolarizing prepulse. Under control conditions, facilitation occurred in Barr $2^{-/-}$but not $\beta a r r 2^{+/+}$neurons. $\boldsymbol{B}$, The use of the two-step protocol caused a prepulseevoked facilitation of $\mathrm{Ba}^{2+}$ currents recorded from $\beta a r r 2^{+/+}$(left) and $\beta a r r 2^{-/-}$(right) neurons in the presence of DAMGO $(1 \mu \mathrm{M})$. C, The depolarizing prepulse also caused facilitation of $\mathrm{Ba}^{2+}$ currents recorded from $\beta a r r 2^{+/+}$(left) and $\beta a r r 2^{-/-}$(right) neurons evoked by the test pulse when GTP- $\gamma$-S $(300 \mu \mathrm{m})$ was included in the electrode. $D$, Mean data from at least five $\beta a r r 2^{+/+}$and $\beta a r r 2^{-/-}$neurons recorded in the presence and absence of either DAMGO or intracellular GTP- $\gamma$-S. The absence of $\beta$-arrestin2 caused a significant increase in the voltage-dependent facilitation in both the absence $\left({ }^{*} p<0.05\right.$, ANOVA, post hoc Tukey's test) and presence $\left({ }^{* *} p<0.01\right)$ of GTP- $\gamma$-S. Error bars represent \pm SEM. the absence of a prepulse (Fig. $6 \mathrm{~B}$ ). The current amplitudes in the presence of DAMGO were enhanced by a depolarizing prepulse to $123 \pm 8$ and $134 \pm 10 \%$ of those recorded in the absence of a prepulse from $\beta a r r 2^{+/+}$and $\beta a r r 2^{-/-}$neurons, respectively (Fig. $6 D)$. Because the inhibition by DAMGO is larger in $\beta a r r 2^{+/+}$ neurons than $\beta a r r 2^{-/-}$neurons (Fig. 1), a similar level of voltage-dependent facilitation in the presence of DAMGO could indicate a greater degree of voltage-dependent reversal of inhibition in $\beta a r r 2^{-1-}$ neurons. However, the depolarizing prepulse caused basal current facilitation in $\beta a r r 2^{-/-}$neurons in the absence of DAMGO that was not seen in $\beta a r r 2^{+/+}$neurons (Fig. $6 A)$. When the basal facilitation of $\beta a r r 2^{-/-}$VGCC activity is taken into consideration, there is little difference in the efficacy of the $80 \mathrm{mV}$ depolarizing prepulse to reverse the inhibitory effect of DAMGO on VGCC activity in $\beta a r r 2^{-/-}$and $\beta a r r 2^{+/+}$neurons.

We further explored the possibility of disrupted inhibitory G-protein coupling to VGCCs caused by the absence of $\beta$-arrestin 2 by comparing the effect on VGCCs of GTP- $\gamma$-S (300 $\mu \mathrm{M})$ applied through the recording electrode to the inside of $\operatorname{\beta arr}^{-/-}$and $\beta a r r 2^{+/+}$neurons. The level of inhibition elicited by GTP- $\gamma$-S in the electrode solution was evaluated using the depolarizing prepulse approach (Fig. 6C). Inclusion of GTP- $\gamma-\mathrm{S}$ in the electrode increased facilitation in both neuronal populations (Fig. 6D). However, as seen under control conditions (Fig. $6 A)$, voltage-dependent facilitation was significantly $(p<0.01)$ greater in $\beta a r r 2^{-/-}$neurons (149 $\pm 7 \% ; n=10$ of control) compared with $\beta$ arr $2^{+/+}$neurons $(125 \pm 5 \%$; $n=13$ ) (Fig. $6 D)$.

Together, these data demonstrate that reduced coupling between $\mu$ receptors and VGCCs in $\beta a r r 2^{-1-}$ DRG neurons is not caused by a disruption of inhibitory G-protein coupling.

\section{Increased constitutive coupling of $\mu$ receptors to VGCCs in} $\boldsymbol{\beta a r r}^{-/-}$neurons

The increased depolarization-evoked facilitation in $\beta a r r 2^{-1-}$ neurons observed under control conditions (Fig. 6A,D) may be caused by greater constitutive inhibition of VGCCs in $\beta a r r 2^{-/-}$ neurons compared with $\beta a r r 2^{+/+}$neurons (Fig. 6). Several GPCRs, including opioid receptors, exhibit constitutive coupling to cellular effectors (Costa and Herz, 1989; Wang et al., 1994; Sadee et al., 2005). Increased constitutive coupling of $\mu$ receptors to VGCCs in $\beta a r r 2^{-/-}$neurons may also give rise to the reduced efficacy of $\mu$ agonists (Fig. 1), because receptors participating in constitutive coupling would not be available for mediating the effects of agonists such as morphine or DAMGO. Naltrexone has negative intrinsic activity and therefore acts as an inverse agonist able to inhibit constitutively active $\mu$ receptors (Sadee et al., 2005). We tested the effect of naltrexone on currents recorded from $\beta a r r 2^{-/-}$and $\beta a r r 2^{+/+}$neurons (Fig. 7). We used the same protocol illustrated in Figure 6 to examine the effect of a prepulse to $80 \mathrm{mV}$ on the current elicited by a test pulse to $10 \mathrm{mV}$ recorded from $\beta a r r 2^{-/-}$and $\beta a r r 2^{+/+}$neurons in the presence of naltrexone. GTP- $\gamma$-S (300 nM) was included in the electrode solution to increase the amplitude of facilitation (Fig. $6 C, D$ ). In the presence of GTP- $\gamma$-S, naltrexone had no significant effect on the level of facilitation in $\beta a r r 2^{-1-}$ neurons. Facilitation induced by the depolarizing prepulse was $139 \pm 8$ and $153 \pm 7 \%(n=6)$ in the presence and absence of naltrexone $(1 \mu \mathrm{M})$, respectively (data not shown). GTP- $\gamma$-S is nonhydrolysable and therefore interacts irreversibly with activated G-protein $\alpha$ subunits. Thus, it is not possible to reverse such an interaction should it have taken place before administration of the inverse agonist naltrexone. There are several mechanisms that may facilitate the exchange of GDP, bound to $\mathrm{G} \alpha$ subunits, by intracellular GTP- $\gamma$-S: (1) endogenous 
A
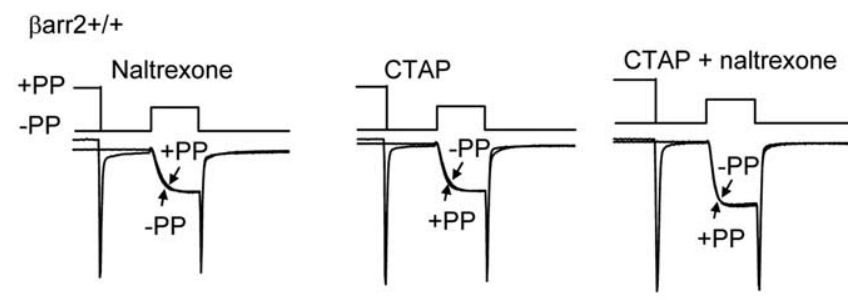

Barr2-/-
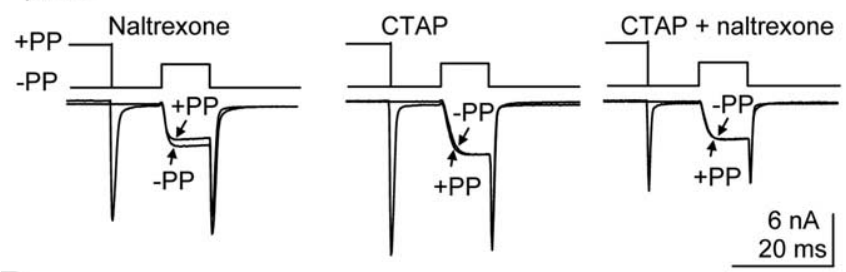

B

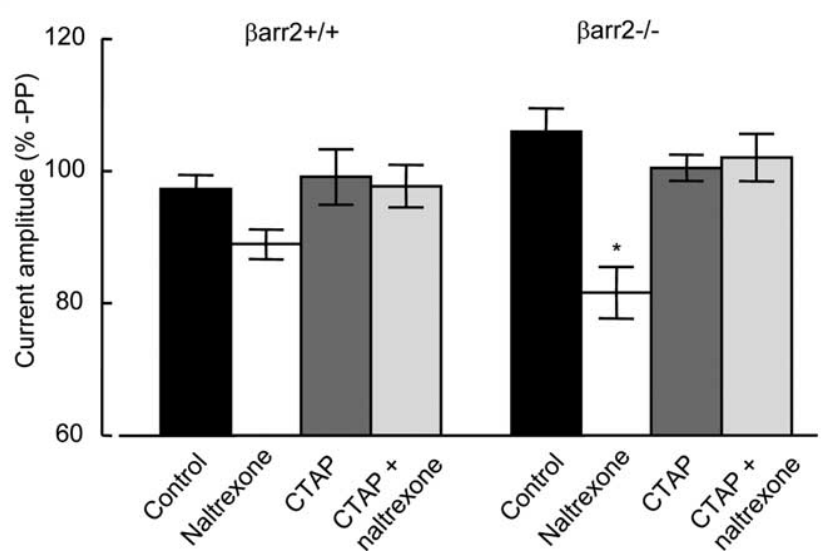

Figure 7. Constitutive inhibitory coupling of $\mu$ receptors to VGC(s in $\beta a r r 2^{-/-}$neurons. $A$, Whole-cell $\mathrm{Ba}^{2+}$ currents recorded from $\beta a r r 2^{+/+}$(top traces) and $\beta a r r 2^{-1-}$ (bottom traces) DRG neurons. Currents were stimulated using a two-step voltage protocol illustrate in Figure 6. Each trace depicts two current sweeps recorded from a cell in the presence (+PP) and absence (-PP) of a depolarizing prepulse to $80 \mathrm{mV}$. Currents were recorded in the presence of the inverse agonist naltrexone $(1 \mu \mathrm{M})$, the neutral antagonist $\operatorname{CTAP}(1 \mu \mathrm{M})$, or a combination of both drugs. Each pair of currents was recorded from a different cell. $\boldsymbol{B}$, The bar graph of percentage facilitation by the $80 \mathrm{mV}$ prepulse in the absence and presence of naltrexone and/or CTAP reveals that neither drug had a significant effect in $\beta$ arr2 ${ }^{+/+}$neurons. In contrast, naltrexone inhibited the amplitude of the $\mathrm{Ba}^{2+}$ current activated in $\beta$ arr2 ${ }^{-1-}$ neurons after the prepulse to $80 \mathrm{mV}$ expressed as a percentage of that recorded in the absence of the prepulse $\left({ }^{*} p<0.01\right.$, ANOVA, post hoc Tukey's test). Error bars represent \pm SEM.

agonist-mediated GPCR activity, (2) constitutive GPCR activity, and (3) intrinsic $G \alpha$ subunit activity. Therefore, although it is possible that naltrexone slows the exchange process by inhibiting constitutive $\mu$ receptor activity in $\beta a r r 2^{-/-}$neurons, this effect may be masked by the other mechanisms in play. Therefore, we performed the same experiment without inclusion of GTP- $\gamma$-S in the recording electrode (Fig. 7A). Naltrexone (1 $\mu \mathrm{M})$ had no effect on the ratio of the current amplitude of the $\mathrm{Ba}^{2+}$ current recorded from $\beta a r r 2^{+/+}$neurons in the presence $\left(I_{+80}\right)$ and absence $\left(I_{-80}\right)$ of a prepulse (Fig. $\left.7 B\right)$. In contrast, naltrexone caused a significant $(p<0.01)$ inhibition of the $I_{+80} / I_{-80}$ ratio recorded from $\beta a r r 2^{-/-}$neurons (Fig. 7B). The effects of inverse agonists such as naltrexone can be reversed by neutral competitive antagonists (Costa and Herz, 1989). We tested the effects of CTAP (Cys-Tyr-D-Trp-Arg-Thr-Pen-Thr- $\left.\mathrm{NH}_{2}\right)(1 \mu \mathrm{M})$, a $\mu$ receptor antagonist that has negligible negative efficacy (Wang et al., 1994), on the $I_{+80} / I_{-80}$ ratio recorded from both $\beta a r r 2^{-1-}$ and $\mathrm{Barr}^{+/+}$neurons (Fig. $7 \mathrm{~A}, \mathrm{~B}$ ). Consistent with the hypothesis that CTAP lacks negative efficacy, the antagonist had no effect on the $I_{+80} / I_{-80}$ ratio recorded from either $\beta a r r 2^{-/-}$or Barr2 $^{+/+}$neurons (Fig. $7 A, B$ ). However, CTAP did prevent the inhibitory effect of naltrexone on the $I_{+80} / I_{-80}$ ratio recorded from $\beta a r r 2^{-1-}$ neurons (Fig. 7B). These data support the hypothesis that naltrexone is acting as an inverse agonist at the $\mu$ receptor to reduce constitutive inhibitory coupling to VGCCs in Barr2 $^{-/-}$neurons but not $\beta a r r 2^{+/+}$neurons. The data suggest that constitutive coupling could account for the reduced efficacy of $\mu$ agonists as inhibitors of VGCCs in $\beta a r r 2^{-/-}$compared with Barr $^{+/+}$neurons.

\section{Constitutive recycling of $\mu$ receptors is impaired in $\beta a r r 2^{-/-}$ DRG neurons}

Despite evidence for the constitutive activity of opioid receptors, there is little information regarding its functional role. Recent studies of other GPCRs suggest that constitutive activity drives constitutive recycling (Morris et al., 2004; Leterrier et al., 2006). Thus, it is possible that the impact of constitutively active GPCRs under normal circumstances is minimized by constitutive internalization. If this is the case, then increased constitutive activity in $\beta a r r 2^{-/-}$neurons could be caused by a deficit of constitutive recycling, leading to an increase in spontaneous inhibitory coupling of $\mu$ receptors to VGCCs. We used flow cytometry (as described in Fig. $2 B, C)$ to compare constitutive recycling in $\mathrm{\beta arr}^{-/-}$and $\beta \mathrm{arr}{ }^{+/+}$neurons. Exposure for $30 \mathrm{~min}$ to monen$\sin (300 \mathrm{nM})$, an inhibitor of $\mu$ receptor recycling that blocks endosomal acidification causing receptor accumulation within the cytoplasm (Koch et al., 1998), decreased cell-surface APCvisualized $\mu$ receptor antibody labeling of $\beta a r r 2^{+/+}$DRG neurons. The FI of monensin-treated $\beta a r r 2^{+/+}$neurons was reduced to $86 \pm 4 \%$ of that of untreated $\beta a r r 2^{+/+}$neurons $\left({ }^{*} p<0.05\right.$, Student's $t$ test; $n=6)$. In contrast, monensin had no effect on $\mu$ receptor levels in $\beta$ arr $2^{-/-}$neurons (FI of $101 \pm 3 \%$ of untreated neurons; $n=10$ ), indicating that constitutive recycling of the $\mu$ receptor is $\beta$-arrestin 2 dependent. These data suggest that $\mu$ receptors are constitutively recycled in wild-type DRG neurons in a monensin-sensitive manner. Such GPCR recycling typically occurs within $200 \mathrm{~nm}$ of the plasma membrane and is therefore undetectable by traditional CLSM. This may account for the $\mu$ receptor labeling shown in Figure $2 A$, which appeared unaffected by $\beta$-arrestin 2 deletion.

\section{Aberrant distribution and phosphorylation of c-Src in $\boldsymbol{\beta a r r 2}^{-/-}$DRG neurons}

A role for $\beta$-arrestin 2 in agonist-induced internalization has been well established for several GPCRs, including the $\beta 2 \mathrm{AR}, \alpha 1 \mathrm{a}$ adrenergic receptors and angiotensin type $1\left(\mathrm{AT}_{1}\right)$ receptors (Lefkowitz, 1998; Fessart et al., 2005; Pediani et al., 2005). Agonist stimulation of the $\beta 2 \mathrm{AR}$ causes $\beta$-arrestin-dependent formation of a complex between the receptor and the nonreceptor tyrosine kinase c-Src (Luttrell et al., 1999). In the case of the $\mathrm{AT}_{1}$ receptor and $\beta 2 \mathrm{AR}, \mathrm{c}-\mathrm{Src}$ is required for normal agonist-induced receptor internalization (Shumay et al., 2002; Fessart et al., 2005). We therefore investigated whether c-Src participates in $\beta$-arrestin2dependent constitutive trafficking of $\mu$ receptors in DRG neurons.

Because $\beta$-arrestins are required for c-Src targeting to GPCRs (Miller et al., 2000), we first examined whether there is aberrant localization of c-Src in $\mathrm{Barr}^{-/-}$neurons. We used highresolution CLSM to compare the cellular distribution of c-Src in $\mathrm{Barr}^{+/+}$and $\mathrm{Barr}^{-/-}$neurons (Fig. 8A). A dense "lattice-like" 
A

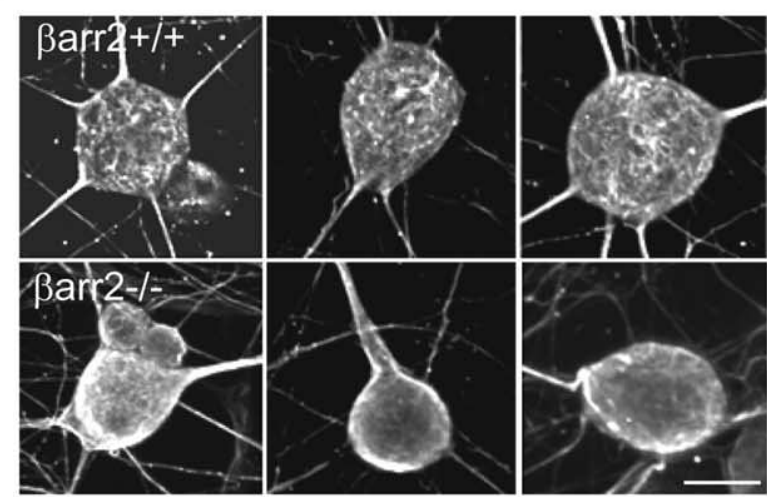

B

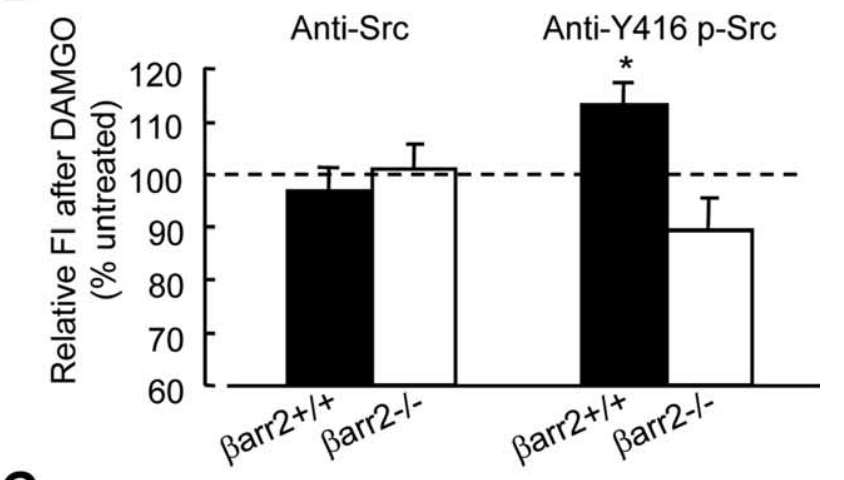

C

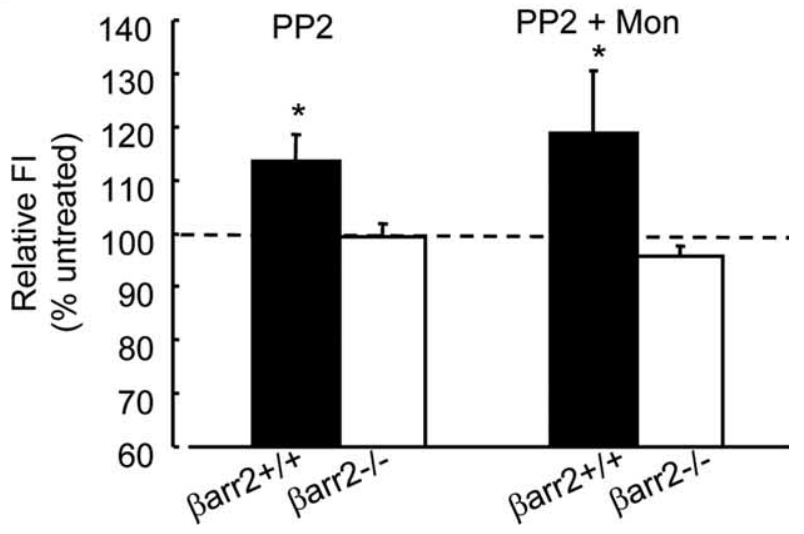

Figure 8. Constitutive trafficking of the $\mu$ receptor is $\beta$-arrestin2 and Src dependent. $\boldsymbol{A}$, Confocal laser-scanning microscopy of c-Src-labeled DRG neurons showed a more dense and structured distribution of c-Src in the cell bodies of $\beta a r r 2^{+/+}$than $\beta a r r 2^{-/-}$neurons. These cells were imaged by taking $\sim 30$ serial $x-y$ scans at $0.4-0.5 \mu \mathrm{m} z$-scale intervals through a $100 \times$ oil-immersion objective and merging the image stack into a single maximum-intensity projection of each cell. Scale bar, $5 \mu \mathrm{m}$. B, Flow cytometry was used to determine the effect of DAMG0, a $\mu$ agonist, on Src (using an APC-conjugated anti-Src antibody) and phospho-Y416 c-Src (using a fluorescein-conjugated anti-Y416 p-Src antibody) on the DRG neurons in R1 (see Fig. 2B, C). FI was expressed relative to that in cells that were not exposed to DAMGO. In Barr ${ }^{+/+}$neurons, DAMGO $(20 \mathrm{~min}, 1 \mu \mathrm{M})$ caused an increase $\left({ }^{*} p<0.05\right)$ in Y416 phosphorylation without affecting the levels of c-Src. There was no increase in Y 416 phosphorylation in $\beta a r r 2^{-/-}$neurons, indicating that $\mu$ agonist activation of c-Src is $\beta$-arrestin2 dependent. $\boldsymbol{C}$, Treatment of $\beta a r r 2^{+/+}$neurons with the c-Src inhibitor PP2 (4h, $\left.10 \mu \mathrm{m}\right)$ increased cellsurface $\mu$ receptor levels relative to untreated neurons ( ${ }^{*} p<0.05 ; n=9$ ) determined by measurement of Fl. In contrast to untreated neurons in which monensin reduced cell-surface $\mu$ receptor levels (see Results), monensin $(300 \mathrm{~nm}$ ) applied during the last 30 min of PP2 treatment had no effect. PP2 had no effect on cell-surface $\mu$ receptor levels in $\beta a r r 2^{-/-}$neurons applied either alone or in combination with monensin. For designation of the neuronal population, see Figure 2, B and C. Statistical significance was determined by the Student's $t$ test. Error bars represent \pm SEM.
c-Src distribution is evident at the cell membrane in $\beta a r r 2^{+/+}$ neurons, whereas $\beta a r r 2^{-/-}$neurons exhibit a less structured c-Src distribution (Fig. $8 A$ ). This apparent qualitative difference in the distribution of $\mathrm{c}$-Src was not evident in the processes of DRGs, perhaps attributable to the detection limits of CLSM. Altered c-Src distribution was hard to discern using immunocytochemistry; therefore, we used an antibody to the phosphorylated catalytic domain of c-Src, Y416 (Lefkowitz, 1998), to determine whether coupling between $\mu$ receptors and $\mathrm{c}$-Src was disrupted by the absence of $\beta$-arrestin2. DAMGO $(1 \mu \mathrm{M})$ exposure for 20 min caused a small but significant increase $(p<0.05$ vs untreated neurons; $n=8$ ) in phosphorylation and hence activation of c-Src in cultured $\beta a r r 2^{+/+}$DRG neurons as quantified by flow cytometry (Fig. 8 B). In contrast, no increase in Y416 phospho-Src was observed after $20 \mathrm{~min}$ of $\beta a r r 2^{-/-}$neuron stimulation by DAMGO. Thus, the appearance of aberrant targeting of c-Src in Barr $^{-1-}$ neurons (Fig. $8 \mathrm{~A}$ ) was accompanied by an inability of DAMGO to induce phosphorylation of c-Src at Y416 (Fig. $8 B$ ).

Inhibition of c-Src activity reduces constitutive recycling in DRG neurons

We examined whether defective c-Src signaling may be responsible for aberrant $\mu$ receptor trafficking and function in $\beta a r r 2^{-/-}$ neurons. Exposure of $\beta a r r 2^{+/+}$neurons to the selective Src family kinase inhibitor PP2 [4-amino-5-(4-chlorophenyl)-( $t$ butyl)pyrazolo[3,4-D]pyrimidine] $(10 \mu \mathrm{M})$ for $4 \mathrm{~h}$ caused a small increase in cell-surface $\mu$ receptor antibody labeling (113 $\pm 4 \%$ of untreated $\beta a r r 2^{+/+}$neurons) determined by flow cytometry (Fig. $8 C)$. The application of PP2 $(10 \mu \mathrm{M})$ for $4 \mathrm{~h}$ with monensin (300 $\mathrm{nM})$ during the final $30 \mathrm{~min}$ of PP2 exposure caused no significant increase in the level of cell-surface $\mu$ receptors compared with the increase observed when $\beta a r r 2^{+/+}$neurons were treated with PP2 alone (Fig. $8 C$ ). These data suggest that SrC inhibition reduces the constitutive internalization of $\mu$ receptors, thereby ablating the effect of monensin on cell-surface receptor levels. PP2 had no effect on cell-surface $\mu$ receptor levels in Barr $^{-1-}$ neurons when applied either alone or in combination with monensin (Fig. 8C). Together, these data are consistent with the hypothesis that defective c-Src signaling results in defective constitutive internalization and recycling of $\mu$ receptors in Barr $^{-/-}$DRG neurons.

\section{Aberrant Src signaling reduces the inhibitory effect of $\mu$ agonists on VGCCs and increases constitutive activity of $\mu$ receptors in $\boldsymbol{\beta a r r}^{-/-}$DRG neurons}

The absence of $\beta$-arrestin from DRG neurons disrupts both c-Src distribution and activation by a $\mu$ receptor agonist (Fig. 8). We investigated whether defective $\mathrm{c}$-Src signaling may also give rise to the aberrant coupling of $\mu$ receptors to VGCCs in $\beta a r r 2^{-/-}$ DRG neurons. The effect of PP2 on inhibition of VGCCs by opioids in $\beta$ arr $2^{+/+}$neurons (Fig. 9A) is similar to the effect of a lack of $\beta$-arrestin2 (Fig. $1 B)$. Application of PP2 $(10 \mu \mathrm{M}, 5 \mathrm{~h}$ before recording) reduced the inhibition by DAMGO $(1 \mu \mathrm{M})$ of VGCCs recorded from $\beta$ arr $2^{+/+}$neurons $(p<0.01)$ (Fig. $\left.9 A\right)$. In contrast, PP2 had no significant effect on the inhibition by DAMGO of VGCCs recorded from Barr $^{-1-}$ neurons (data not shown). The reduction of the inhibitory effect of morphine (1 $\mu \mathrm{M})$ by PP2 in $\beta a r r 2^{+/+}$neurons was statistically insignificant. However, together these data support the hypothesis that the reduced efficacy of VGCC inhibition by $\mu$ agonists in $\beta a r r 2^{-/-}$ neurons is caused by aberrant c-Src signaling.

In $\beta$ arr $2^{-/-}$neurons, reduced efficacy of $\mu$ agonists (Fig. 1) is associated with increased agonist-independent constitutive $\mu$ re- 
A

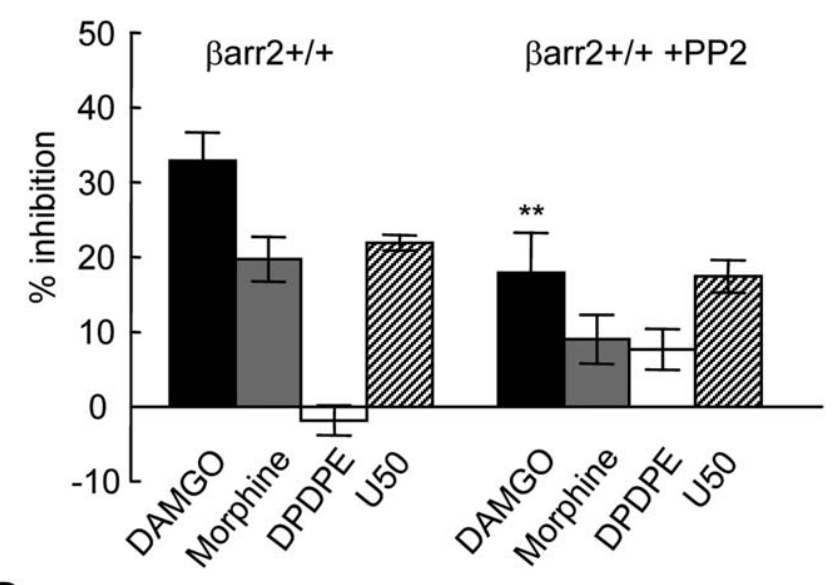

B

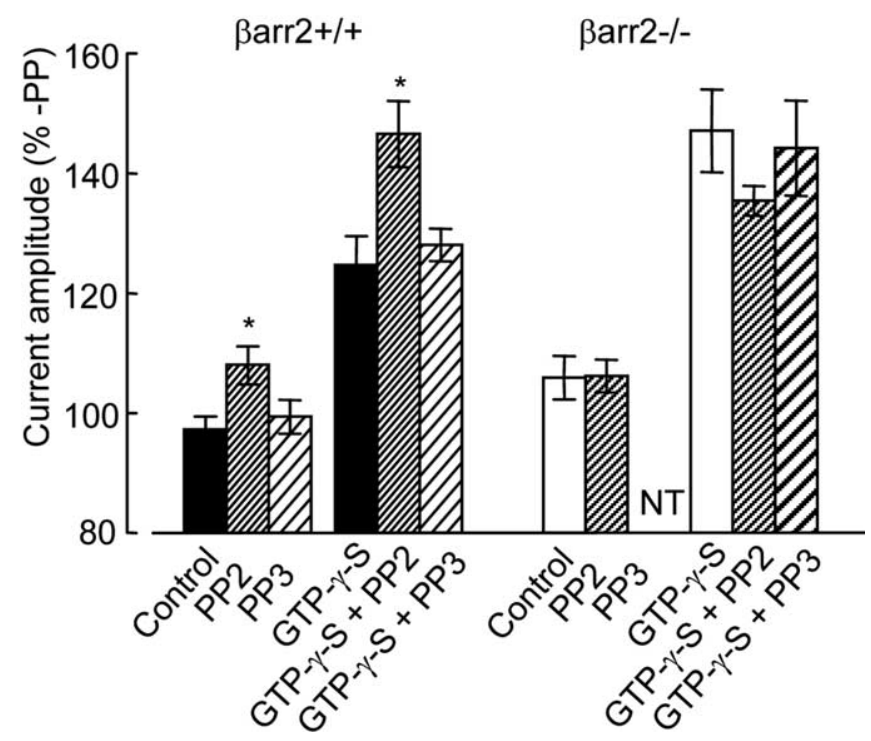

Figure 9. The Src inhibitor PP2 mimics the effects of the absence of $\beta$-arrestin2 on $\mu$ receptor coupling to VGCCs. $\boldsymbol{A}$, The bar graph illustrates the amplitudes of opioid-mediated inhibition of $\mathrm{Ca}^{2+}$ currents recorded from $\beta a r r 2^{+/+}$DRG neurons in the absence or presence of the Src inhibitor PP2. Opioids were applied at a concentration of $1 \mu \mathrm{m}$, whereas $\mathrm{Ca}^{2+}$ currents were activated by depolarizing from -80 to $10 \mathrm{mV}$ (as shown in Fig. 1A). Statistical significance $\left({ }^{* *} p<0.01\right.$ ) was determined using ANOVA with the post hoc Tukey's test. $\boldsymbol{B}$, Voltagedependent facilitation of $\mathrm{Ba}^{2+}$ currents recorded from $\beta a r r 2^{+/+}$and $\beta a r r 2^{-/-}$neurons with and without GTP- $\gamma$-S $(300 \mu \mathrm{m})$ in the recording electrode (voltage protocol illustrated in Fig. 5A). The Src inhibitor PP2 increased the level of facilitation (in both the presence and absence of GTP- $\gamma$-S) in $\beta a r r 2^{+/+}$but not $\beta a r r 2^{-/-}$neurons $\left({ }^{*} p<0.05\right)$. In contrast, PP3 had no effect on facilitation in either $\beta a r r 2^{+/+}$or $\beta a r r 2^{-/-}$neurons. Statistical significance was determined using ANOVA with the post hoc Tukey's test. Error bars represent \pm SEM.

ceptor inhibitory coupling to VGCCs (Fig. 7). We examined whether reduced inhibition by DAMGO and morphine caused by PP2 inhibition of Src is also associated with increased constitutive inhibition of VGCCs in $\beta a r r 2^{+/+}$DRG neurons (Fig. 9B). We tested the effect of PP2 application ( $10 \mu \mathrm{M}, 5 \mathrm{~h}$ before recording) on prepulse-evoked facilitation recorded from both $\beta a r r 2^{+/+}$ and $\beta a r r 2^{-1-}$ neurons (Fig. 9B). Consistent with the hypothesis that defective Src signaling gives rise to increased constitutive inhibition, PP2 caused an increase in the $I_{+80} / I_{-80}$ ratio recorded from arr $^{+/+}$neurons $(p<0.05)$ (Fig. 9B). This effect was evident either with or without GTP- $\gamma$-S $(300 \mu \mathrm{M})$ in the recording electrode. In contrast, the inactive analog of PP2, PP3 (4-
amino-7-phenylpyrazol[3,4-D]pyrimidine) (10 $\mu \mathrm{M}$, applied $5 \mathrm{~h}$ before recording), had no effect on the $I_{+80} / I_{-80}$ ratio in recordings from $\beta a r r 2^{+/+}$DRG neurons. The increase in the $I_{+80} / I_{-80}$ ratio induced by PP2 (Fig. $9 B$ ) mimicked that caused by the absence of $\beta$-arrestin2 in $\beta$ arr $2^{-1-}$ neurons (Fig. 6). Consistent with the hypothesis that defective Src signaling gives rise to increased constitutive $\mu$ receptor coupling to VGCCs in the absence of $\beta$-arrestin2, PP2 had no effect on the $I_{80} / I_{-80}$ ratio in Barr2 $^{-/-}$neurons.

\section{Discussion}

A lack of $\beta$-arrestin 2 reduced the efficacy of $\mu$ receptor agonists in DRG neurons without significantly affecting VDCC inhibition by $\delta, \kappa$, or $\mathrm{GABA}_{\mathrm{B}}$ receptor agonists. This deficit occurred without a change in the contribution of $\mathrm{N}$-type channels. Furthermore, there was no change in the relative proportion of voltagedependent versus voltage-independent inhibitory $\mu$ receptor coupling to VGCCs.

The reduction in the morphine- and DAMGO-mediated inhibition of VGCCs was accompanied by increased constitutive coupling of $\mu$ receptors to VGCCs in $\beta a r r 2^{-1-}$ neurons and an absence of monensin-sensitive constitutive $\mu$ receptor recycling. The absence of $\beta$-arrestin 2 also prevented DAMGO from activating $\mathrm{c}-\mathrm{Src}$, a functional deficit associated with an aberrant localization of the kinase in $\beta a r r 2^{-/-}$neurons. Accordingly, the phenotype of $\beta a r r 2^{-/-}$neurons was mimicked in $\beta$ arr $2^{+/+}$neurons treated with the Src inhibitor PP2. These findings suggest a novel role for the $\beta$-arrestin $2 / \mathrm{c}$-Src complex, recycling constitutively active $\mu$ receptors, thus limiting tonic coupling to cellular effectors.

Agonist activation of GPCRs recruits $\beta$-arrestins (Lefkowitz and Shenoy, 2005) which link the membrane-bound receptor with clathrin and $\alpha$-adaptin-2 to initiate recycling and resensitization (Pippig et al., 1995; Goodman et al., 1996; Laporte et al., $1999,2000)$. $\beta$-Arrestin would therefore be expected to accelerate $\mu$ receptor desensitization (Lowe et al., 2002) and enhance analgesic tolerance to morphine. However, $\beta a r r 2^{-/-}$mice exhibit delayed tolerance and enhanced morphine-evoked analgesia and reward, whereas respiratory depression and constipation are diminished (Bohn et al., 1999, 2000, 2002, 2004; Raehal et al., 2005). This complex phenotype cannot be explained solely by the classical role of $\beta$-arrestins in promoting internalization of agonist-activated receptors.

Morphine is unusual among agonists; it causes little $\mu$ receptor internalization (Keith et al., 1996). Indeed, this property has been blamed for pronounced tolerance associated with morphine exposure (Whistler et al., 1999; Evans, 2000). The RAVE (for relative activity versus endocytosis) hypothesis postulates that non-internalizing $\mu$ agonists cause greater tolerance than do internalizing agonists. However, recent studies of $\mu$ receptor coupling to inwardly rectifying $\mathrm{K}^{+}$channels demonstrate that neither the onset of nor the recovery from receptor desensitization (phenomena linked to tolerance) are ablated by inhibitors of internalization (Arttamangkul et al., 2006; Dang and Christie, 2006). In fact, recovery from desensitization occurs faster in the presence of inhibitors of internalization (Dang and Christie, 2006). Furthermore, the onset of desensitization, measured by $\mu$ receptor-VGCC coupling, is unrelated to internalization in DRG neurons (Walwyn et al., 2006). Consistent with these studies, we found no difference in the onset of desensitization of $\mu$ receptor coupling to VGCCs activated by morphine or DAMGO in Barr $^{+/+}$and Barr2 $^{-/-}$neurons. Therefore, mechanisms other 
than classical agonist-mediated endocytosis must be at play to explain morphine-induced tolerance.

In addition to their role in agonist-induced internalization, $\beta$-arrestins participate in constitutive GPCR recycling (Pediani et al., 2005; Leterrier et al., 2006). In the absence of $\mu$ agonists, monensin, an inhibitor of GPCR recycling that accumulates receptors within the cytoplasm (Koch et al., 1998), reduced cellsurface $\mu$ receptor expression in $\beta a r r 2^{+/+}$neurons. These data support a role for ongoing constitutive recycling of neuronal $\mu$ receptors similar to that observed previously for recombinant receptors (Alvarez et al., 2002; Johnson et al., 2006, Walwyn et al., 2006). A lack of monensin-sensitive constitutive recycling in $\beta a r r 2^{-1-}$ neurons indicates a requirement for $\beta$-arrestin 2 in keeping with other GPCRs that constitutively recycle in a $\beta$-arrestin-dependent manner (Pula et al., 2004; Pediani et al., 2005).

$\beta$-Arrestins target several proteins to $\mu$ receptors, including c-Src, which participates in $\mu$ receptor signaling (Kato et al., 2006). c-Src was refractory to activation by DAMGO in $\mathrm{\beta arr}^{-/-}$ neurons. The role of $\mathrm{c}$-Src in facilitating ligand-induced internalization of the $\beta 2 \mathrm{AR}$ is well established (Shumay et al., 2002), affecting both the clathrin (Luttrell et al., 1999; Miller et al., 2000; van Koppen 2001; Fessart et al., 2005) and caveolin (Shajahan et al., 2004; Khan et al., 2006) internalization pathways. Inhibition of Src in $\beta a r r 2^{+/+}$neurons by PP2 increased $\mu$ receptor surface expression and abolished the monensin-induced downregulation of surface receptors. It is therefore consistent that c-Src inactivity, either through $\beta$-arrestin 2 deletion or pharmacological inhibition, affected internalization and recycling, increasing cellsurface $\mu$ receptors. We therefore conclude that $\mathrm{c}-\mathrm{Src}$, recruited by $\beta$-arrestin 2 , is required for constitutive $\mu$ receptor recycling. Interestingly, p38 MAPK also initiates $\mu$ receptor constitutive internalization (Mace et al., 2005). Because MAPK and c-Src transduction pathways are orchestrated by $\beta$-arrestins (Lefkowitz and Shenoy, 2005), it will be interesting to establish the point at which their actions converge to regulate $\mu$ receptor recycling.

Inhibitory coupling of both $\mu$ and $\mathrm{GABA}_{\mathrm{B}}$ receptors to $\mathrm{N}$-type VGCCs exhibits voltage-dependent and voltage-independent components (Richman et al., 2004; Raingo et al., 2007). The former requires the interaction of Src with a specific motif within a variant of the $\mathrm{Ca}_{\mathrm{V}} 2.2 \alpha 1$ subunit that contains exon $37 \mathrm{a}$ (Raingo et al., 2007). Exons 37a and b are mutually exclusive in rat DRG neurons (Bell et al., 2004). A reduction in Src signaling caused by a lack of $\beta$-arrestin 2 could reduce voltage-independent coupling of $\mu$ receptors to $\mathrm{N}$-type channels. However, we observed no reduction in the voltage dependence of inhibition by DAMGO in Barr $2^{-1-}$ neurons. The whole-cell patch-clamp configuration may minimize the contribution of voltage-independent coupling to N-type channels (Raingo et al., 2007). Furthermore, the expression of exon $37 \mathrm{a}$ of the $\mathrm{Ca}_{\mathrm{V}} 2.2 \alpha 1$ subunit is enriched is specific rat DRG neurons, particularly those containing lowthreshold T-type VGCCs. $\mathrm{Ca}^{2+}$ current-voltage relationships revealed a lack of a low-threshold component; therefore, exon 37a may have been underrepresented in the cultured mouse neurons used in our study.

$\beta$-Arrestin 1 participates in the internalization of N-type channels, raising the possibility that $\beta$-arrestin 2 may play a similar role (Puckerin et al., 2006). However, we found that the functional contribution of $\mathrm{N}$-type channels in DRG neurons was unaffected by the absence of $\beta$-arrestin 2 . Thus, $\beta$-arrestin 1 may play a specific role in regulating $\mathrm{N}$-type channel internalization/recycling. It remains to be determined whether this involves c-Src.

There is increasing evidence supporting a role for agonist- independent GPCR activity in triggering receptor recycling. Although neutral competitive antagonists are able to internalize with constitutively recycling GPCRs, the application of inverse agonists inhibits recycling, leading to cell-surface receptor upregulation (McCune et al., 2000; Miserey-Lenkei et al., 2002; Morris et al., 2004; Leterrier et al., 2006). Furthermore, mutations in the $\mu$ receptor, which enhance constitutive activity, also increase agonist-independent recycling in a manner that can be inhibited by inverse agonists (Li et al., 2001).

Many (perhaps all) wild-type GPCRs exhibit agonistindependent constitutive coupling to G-proteins (Costa and Herz, 1989; Costa and Cotecchia, 2005). Interestingly, the constitutive activity of $\mu$ receptors increases with morphine exposure and may participate in tolerance (Wang et al., 1994; Sadee et al., 2005). The inverse agonist naltrexone inhibits the constitutive activity of $\mu$ receptors, whereas the neutral antagonist CTAP lacks negative efficacy but can displace and thereby inhibit the action of naltrexone. We assayed $\mu$ receptor constitutive activity by exploiting the ability of strong depolarization to reverse inhibitory coupling to VGCCs. A strong depolarization drives $\mathrm{G} \beta \gamma$ subunits off of inhibited $\mathrm{N}$ - and P/Q-type channels, causing current facilitation (Ikeda, 1996). Depolarizing prepulses were relatively ineffective at facilitating currents in $\beta a r r 2^{+/+}$neurons. In contrast, facilitation was significantly enhanced in $\beta a r r 2^{-/-}$neurons and in $\beta a r r 2^{+/+}$neurons treated with the Src inhibitor PP2. The facilitation in $\beta a r r 2^{-/-}$neurons was abolished by naltrexone but not by CTAP. CTAP did prevent the inhibitory effect of naltrexone on voltage-dependent facilitation. Therefore, a lack of c-Src activity caused by the absence of $\beta$-arrestin 2 increased the constitutive $\mu$ receptor inhibition of VGCCs.

Together, our data suggest that c-Src-dependent $\mu$ receptor recycling limits the presence of constitutively active receptors in the cell membrane, thus minimizing constitutive inhibition of VGCCs. We hypothesize that constitutive $\mu$ receptor activity recruits $\beta$-arrestin 2 and $\mathrm{c}$-Src, leading to constitutive recycling, returning the $\mu$ receptor back to the cell membrane in a quiescent state. How might a deficit in this process, caused by the absence of $\beta$-arrestin2, give rise to reduced tolerance to morphine in $\operatorname{\beta arr}^{-/-}$mice? In $\beta a r r 2^{+/+}$neurons, prolonged morphine exposure may increase $\mu$ receptor constitutive activity (Wang et al., 1994), triggering increased $\beta$-arrestin $2 /$ Src-dependent recycling. More receptors would therefore be located beneath the cell surface, perhaps deactivated by the action of Src. These events may contribute to morphine tolerance. In comparison, in the absence of $\beta$-arrestin 2 , there is a failure of internalization and recycling of constitutively active receptors. Therefore, more active receptors will be located in the membrane even after morphine exposure. This scenario may also contribute to the increased analgesic activity of morphine in $\beta$ arr $2^{-/-}$mice (Bohn et al., 2000).

Morphine preferentially recruits $\beta$-arrestin 2 to the $\mu$ receptor (Bohn et al., 2004). We hypothesize that $\mu$ agonists, which are poor inducers of constitutive activity, less effectively recruit $\beta$-arrestin 2 and cause less tolerance. Drug-induced downregulation of the $\beta$-arrestin2-mediated signaling process may ameliorate tolerance associated with analgesic opioids. Our data demonstrating that c-Src mediates many of the actions of $\beta$-arrestin 2 on the $\mu$ receptor raise the possibility that this kinase may also be a suitable target for modulation of the therapeutic profiles of $\mu$ agonists.

\section{References}

Alvarez VA, Arttamangkul S, Dang V, Salem A, Whistler JL, Von Zastrow M, Grandy DK, Williams JT (2002) $\mu$-Opioid receptors: Ligand-dependent 
activation of potassium conductance, desensitization, and internalization. J Neurosci 22:5769-5776.

Arttamangkul S, Torrecilla M, Kobayashi K, Okano H, Williams JT (2006) Separation of $\mu$-opioid receptor desensitization and internalization: endogenous receptors in primary neuronal cultures. J Neurosci 26:4118-4125.

Bell TJ, Thaler C, Castiglioni AJ, Helton TD, Lipscombe D (2004) Cellspecific alternative splicing increases $\mathrm{Ca}^{2+}$ channel current density in the pain pathway. Neuron 41:3-4.

Bohn LM, Lefkowitz RJ, Gainetdinov RR, Peppel K, Caron MG, Lin FT (1999) Enhanced morphine analgesia in mice lacking $\beta$-arrestin 2. Science 286:2495-2498.

Bohn LM, Gainetdinov RR, Lin FT, Lefkowitz RJ, Caron MG (2000) $\mu$-Opioid receptor desensitization by $\beta$-arrestin- 2 determines morphine tolerance but not dependence. Nature 408:720-723.

Bohn LM, Lefkowitz RJ, Caron MG (2002) Differential mechanisms of morphine antinociceptive tolerance revealed in $\beta$-arrestin- 2 knock-out mice. J Neurosci 22:10494-10500.

Bohn LM, Dykstra LA, Lefkowitz RJ, Caron MG, Barak LS (2004) Relative opioid efficacy is determined by the complements of the G proteincoupled receptor desensitization machinery. Mol Pharmacol 66:106-112.

Cen B, Xiong Y, Ma L, Pei G (2001) Direct and differential interaction of $\beta$-arrestins with the intracellular domains of different opioid receptors. Mol Pharmacol 59:758-764.

Chen J, Sochivko D, Beck H, Marechal D, Wiestler OD, Becker AJ (2001) Activity-induced expression of common reference genes in individual CNS neurons. Lab Invest 81:913-916.

Costa T, Cotecchia S (2005) Historical review: Negative efficacy and the constitutive activity of G-protein-coupled receptors. Trends Pharmacol Sci 26:618-624.

Costa T, Herz A (1989) Antagonists with negative intrinsic activity at $\delta$ opioid receptors coupled to GTP-binding proteins. Proc Natl Acad Sci USA 86:7321-7325.

Dang V, Christie, MJ (2006) Beta-arrestin2 independent regulation of mu opioid receptor in locus coeruleus neurons. Soc Neurosci Abstr 32:426.11.

Diverse-Pierluissi M, Goldsmith PK, Dunlap K (1995) Transmittermediated inhibition of N-type calcium channels in sensory neurons involves multiple GTP-binding proteins and subunits. Neuron 14:191-200.

Evans CJ (2000) Agonist selective $\mu$-opioid receptor trafficking in rat central nervous system. Mol Psychiatry 5:121.

Fessart D, Simaan M, Laporte SA (2005) c-Src regulates clathrin adapter protein 2 interaction with $\beta$-arrestin and the angiotensin II type 1 receptor during clathrin-mediated internalization. Mol Endocrinol 19:491-503.

Goodman Jr OB, Krupnick JG, Santini F, Gurevich VV, Penn RB, Gagnon AW, Keen JH, Benovic JL (1996) $\beta$-Arrestin acts as a clathrin adaptor in endocytosis of the $\beta 2$-adrenergic receptor. Nature 383:447-450.

Groer CE, Tidgewell K, Moyer RA, Harding WW, Rothman RB, Prisinzano TE, Bohn LM (2007) An opioid agonist that does not induce $\mu$ opioid receptor - arrestin interactions or receptor internalization. Mol Pharmacol 71:549-557.

Guarna M, Bartolini A, Ghelardini C, Galeotti N, Bracci L, Stefano GB, Bianchi E (2003) Anti- $\mu$ opioid antiserum against the third external loop of the cloned $\mu$-opioid receptor acts as a $\mu$ receptor neutral antagonist. Brain Res Mol Brain Res 119:100-110.

Haberstock-Debic H, Kim KA, Yu YJ, von Zastrow M (2005) Morphine promotes rapid, arrestin-dependent endocytosis of $\mu$-opioid receptors in striatal neurons. J Neurosci 25:7847-7857.

Ikeda SR (1996) Voltage-dependent modulation of N-type calcium channels by G-protein $\beta \gamma$ subunits. Nature 380:255-258.

Johnson EA, Oldfield S, Braksator E, Gonzalez-Cuello A, Couch D, Hall KJ, Mundell SJ, Bailey CP, Kelly E, Henderson G (2006) Agonist-selective mechanisms of $\mu$-opioid receptor desensitization in human embryonic kidney 293 cells. Mol Pharmacol 70:676-685.

Kato H, Narita M, Miyoshi K, Narita M, Asato M, Hareyama N, Nozaki H, Takagi T, Suzuki M, Suzuki T (2006) Implication of Src family kinasedependent phosphorylation of NR2B subunit-containing NMDA receptor in the rewarding effect of morphine. Nihon Shinkei Seishin Yakurigaku Zasshi 26:119-124.

Keith DE, Murray SR, Zaki PA, Chu PC, Lissin DV, Kang L, Evans CJ, von Zastrow M (1996) Morphine activates opioid receptors without causing their rapid internalization. J Biol Chem 271:19021-19024.
Khan EM, Heidinger JM, Levy M, Lisanti MP, Ravid T, Goldkorn T (2006) Epidermal growth factor receptor exposed to oxidative stress undergoes Src- and caveolin-1-dependent perinuclear trafficking. J Biol Chem 281:14486-14493.

Koch T, Schulz S, Schroder H, Wolf R, Raulf E, Hollt V (1998) Carboxylterminal splicing of the rat $\mu$ opioid receptor modulates agonist-mediated internalization and receptor resensitization. J Biol Chem 273:13652-13657.

Koch T, Widera A, Bartzsch K, Schulz S, Brandenburg LO, Wundrack N, Beyer A, Grecksch G, Hollt V (2005) Receptor endocytosis counteracts the development of opioid tolerance. Mol Pharmacol 67:280-287.

Kohout TA, Lefkowitz RJ (2003) Regulation of G protein-coupled receptor kinases and arrestins during receptor desensitization. Mol Pharmacol 63:9-18.

Laporte SA, Oakley RH, Zhang J, Holt JA, Ferguson SS, Caron MG, Barak LS (1999) The $\beta 2$-adrenergic receptor/ $\beta$ arrestin complex recruits the clathrin adaptor AP-2 during endocytosis. Proc Natl Acad Sci USA 96:3712-3717.

Laporte SA, Oakley RH, Holt JA, Barak LS, Caron MG (2000) The interaction of $\beta$-arrestin with the AP-2 adaptor is required for the clustering of $\beta 2$-adrenergic receptor into clathrin-coated pits. J Biol Chem 275:23120-23126.

Lefkowitz RJ (1998) G protein-coupled receptors. III. New roles for receptor kinases and $\beta$-arrestins in receptor signaling and desensitization. J Biol Chem 273:18677-18680.

Lefkowitz RJ, Shenoy SK (2005) Transduction of receptor signals by $\beta$-arrestins. Science 308:512-517.

Leterrier C, Laine J, Darmon M, Boudin H, Rossier J, Lenkei Z (2006) Constitutive activation drives compartment-selective endocytosis and axonal targeting of type 1 cannabinoid receptors. J Neurosci 26:3141-3153.

Li J, Chen C, Huang P, Liu-Chen LY (2001) Inverse agonist up-regulates the constitutively active D3.49(164)Q mutant of the rat $\mu$-opioid receptor by stabilizing the structure and blocking constitutive internalization and down-regulation. Mol Pharmacol 60:1064-1075.

Lowe JD, Celver JP, Gurevich VV, Chavkin C (2002) $\mu$-Opioid receptors desensitize less rapidly than $\delta$-opioid receptors due to less efficient activation of arrestin. J Biol Chem 277:15729-15735.

Luttrell LM, Ferguson SS, Daaka Y, Miller WE, Maudsley S, Della Rocca GJ, Lin F, Kawakatsu H, Owada K, Luttrell DK, Caron MG, Lefkowitz RJ (1999) $\beta$-Arrestin-dependent formation of $\beta 2$ adrenergic receptor-Src protein kinase complexes. Science 283:655-661.

Mace G, Miaczynska M, Zerial M, Nebreda AR (2005) Phosphorylation of EEA1 by p38 MAP kinase regulates $\mu$ opioid receptor endocytosis. EMBO J 24:3235-3246.

McCune DF, Edelmann SE, Olges JR, Post GR, Waldrop BA, Waugh DJ, Perez DM, Piascik MT (2000) Regulation of the cellular localization and signaling properties of the $\alpha_{1 \mathrm{~B}}$ - and $\alpha_{1 \mathrm{D}}$-adrenoceptors by agonists and inverse agonists. Mol Pharmacol 57:659-666.

Miller WE, Maudsley S, Ahn S, Khan KD, Luttrell LM, Lefkowitz RJ (2000) $\beta$-Arrestin1 interacts with the catalytic domain of the tyrosine kinase c-SRC. Role of $\beta$-arrestin1-dependent targeting of c-SRC in receptor endocytosis. J Biol Chem 275:11312-11319.

Miserey-Lenkei S, Parnot C, Bardin S, Corvol P, Clauser E (2002) Constitutive internalization of constitutively active agiotensin II $\mathrm{AT}_{1 \mathrm{~A}}$ receptor mutants is blocked by inverse agonists. J Biol Chem 277:5891-5901.

Morris DP, Price RR, Smith MP, Lei B, Schwinn DA (2004) Cellular trafficking of human $\alpha$ la-adrenergic receptors is continuous and primarily agonist-independent. Mol Pharmacol 66:843-854.

Oakley RH, Laporte SA, Holt JA, Caron MG, Barak LS (2000) Differential affinities of visual arrestin, $\beta$ arrestin 1 , and $\beta$ arrestin2 for G proteincoupled receptors delineate two major classes of receptors. J Biol Chem 275:17201-17210.

Paing MM, Stutts AB, Kohout TA, Lefkowitz RJ, Trejo J (2002) $\beta$-Arrestins regulate protease-activated receptor-1 desensitization but not internalization or down-regulation. J Biol Chem 277:1292-1300.

Passmore GM (2005) Dorsal root ganglion neurones in culture: a model system for identifying novel analgesic targets? J Pharmacol Toxicol Methods 51:201-208.

Pediani JD, Colston JF, Caldwell D, Milligan G, Daly CJ, McGrath JC (2005) $\beta$-Arrestin-dependent spontaneous $\alpha$ la-adrenoceptor endocytosis causes intracellular transportation of $\alpha$-blockers via recycling compartments. Mol Pharmacol 67:992-1004. 
Pippig S, Andexinger S, Lohse MJ (1995) Sequestration and recycling of $\beta 2$-adrenergic receptors permit receptor resensitization. Mol Pharmacol 47:666-676.

Puckerin A, Liu L, Permaul N, Carman P, Lee J, Diverse-Pierluissi MA (2006) Arrestin is required for agonist-induced trafficking of voltage-dependent $\mathrm{Ca}^{2+}$ channels. J Biol Chem 281:31131-31141.

Pula G, Mundell SJ, Roberts PJ, Kelly E (2004) Agonist-independent internalization of metabotropic glutamate receptor la is arrestin- and clathrindependent and is suppressed by receptor inverse agonists. J Neurochem 89:1009-1020.

Raehal KM, Walker JK, Bohn LM (2005) Morphine side effects in $\beta$-arrestin2 knockout mice. J Pharmacol Exp Ther 314:1195-1201.

Raingo J, Castiglioni AJ, Lipscombe D (2007) Alternative splicing controls $\mathrm{G}$ protein-dependent inhibition of N-type $\mathrm{Ca}^{2+}$ channels in nociceptors. Nat Neurosci 10:285-292.

Richman RW, Tombler E, Lau KK, Anantharam A, Rodriguez J, O’Bryan JP, Diverse-Pierluissi MA (2004) $\mathrm{N}$-type $\mathrm{Ca}^{2+}$ channels as scaffold proteins in the assembly of signaling molecules for $\mathrm{GABA}_{\mathrm{B}}$ receptor effects. J Biol Chem 279:24649-24658.

Rusin KI, Moises HC (1995) $\mu$-Opioid receptor activation reduces multiple components of high-threshold calcium current in rat sensory neurons. J Neurosci 15:4315-4327.

Sadee W, Wang D, Bilsky EJ (2005) Basal opioid receptor activity, neutral antagonists, and therapeutic opportunities. Life Sci 76:1427-1437.

Seachrist JL, Anborgh PH, Ferguson SS (2000) $\beta 2$-Adrenergic receptor internalization, endosomal sorting, and plasma membrane recycling are regulated by rab GTPases. J Biol Chem 275:27221-27228.

Shajahan AN, Timblin BK, Sandoval R, Tiruppathi C, Malik AB, Minshall RD (2004) Role of Src-induced dynamin-2 phosphorylation in caveolaemediated endocytosis in endothelial cells. J Biol Chem 279:20392-20400.

Shumay E, Song X, Wang HY, Malbon CC (2002) pp60Src mediates insulin-stimulated sequestration of the $\beta 2$-adrenergic receptor: insulin stimulates pp60Src phosphorylation and activation. Mol Biol Cell 13:3943-3954.

Tohgo A, Choy EW, Gesty-Palmer D, Pierce KL, Laporte S, Oakley RH, Caron MG, Lefkowitz RJ, Luttrell LM (2003) The stability of the G proteincoupled receptor- $\beta$-arrestin interaction determines the mechanism and functional consequence of ERK activation. J Biol Chem 278:6258-6267.

van Koppen CJ (2001) Multiple pathways for the dynamin-regulated internalization of muscarinic acetylcholine receptors. Biochem Soc Trans 29:505-508.

Walwyn WM, Keith Jr DE, Wei W, Tan AM, Xie CW, Evans CJ, Kieffer BL, Maidment NT (2004) Functional coupling, desensitization and internalization of virally expressed $\mu$ opioid receptors in cultured dorsal root ganglion neurons from $\mu$ opioid receptor knockout mice. Neuroscience 123:111-121.

Walwyn W, Maidment NT, Sanders M, Evans CJ, Kieffer BL, Hales TG (2005) Induction of $\delta$ opioid receptor function by up-regulation of membrane receptors in mouse primary afferent neurons. Mol Pharmacol 68:1688-1698.

Walwyn WM, Wei W, Xie CW, Chiu K, Kieffer BL, Evans CJ, Maidment NT (2006) $\mu$ Opioid receptor-effector coupling and trafficking in dorsal root ganglia neurons. Neuroscience 142:493-503.

Wang Z, Bilsky EJ, Porreca F, Sadee W (1994) Constitutive $\mu$ opioid receptor activation as a regulatory mechanism underlying narcotic tolerance and dependence. Life Sci 54:PL339-PL350.

Whistler JL, von Zastrow M (1998) Morphine-activated opioid receptors elude desensitization by $\beta$-arrestin. Proc Natl Acad Sci USA 95:9914-9919.

Whistler JL, Chuang HH, Chu P, Jan LY, von Zastrow M (1999) Functional dissociation of $\mu$ opioid receptor signaling and endocytosis: implications for the biology of opiate tolerance and addiction. Neuron 23:737-746.

Williams JT, Christie MJ, Manzoni O (2001) Cellular and synaptic adaptations mediating opioid dependence. Physiol Rev 81:299-343. 